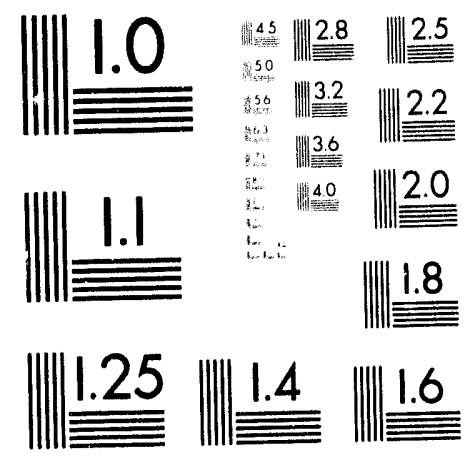



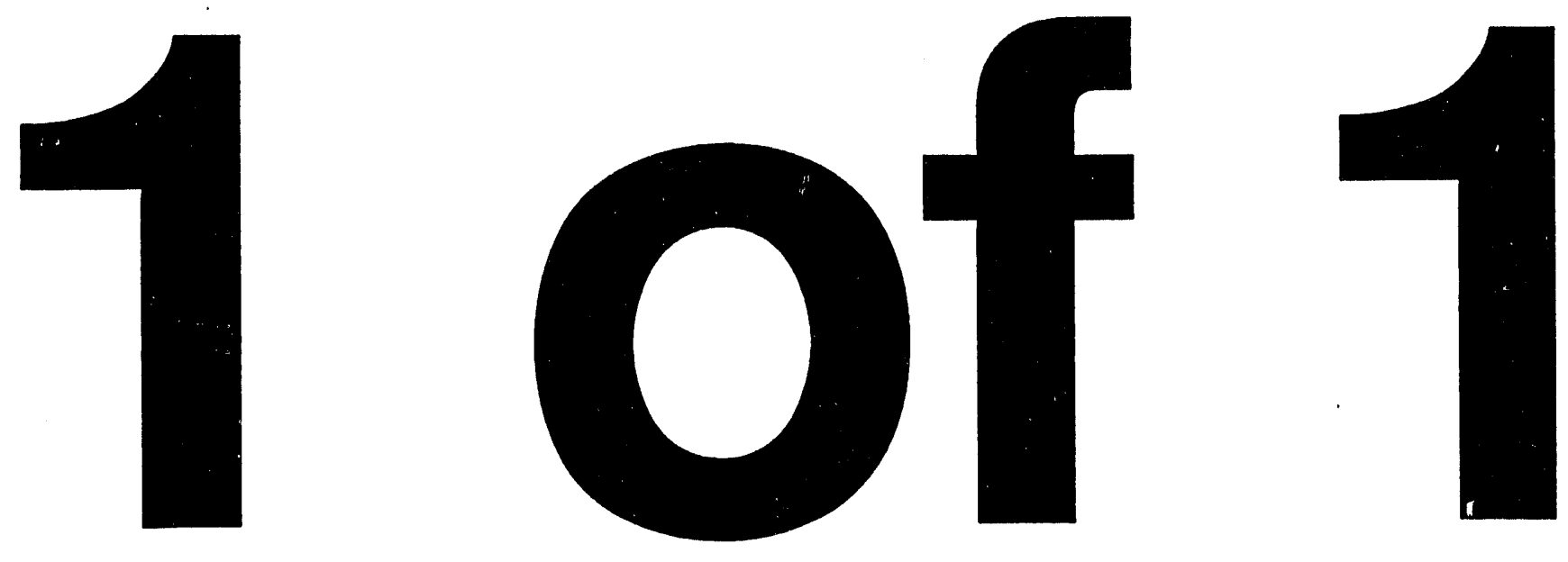


\section{FINDING OF NO SIGNIFICANT IMPACT FOR THE INTERIM ACTION \\ FOR CLEANUP OF PIT 9 AT \\ THE RADIOACTIVE WASTE MANAGEMENT COMPLEX, IDAHO NATIONAL ENGINEERING LABORATORY}

AGENCY: Department of Energy

ACTION: Finding of No Significant Impact

SUMMARY: The Department of Energy (DOE) has prepared an environmental assessment (EA), DOE/EA-0854, for an interim action under the Comprehensive Environmental Response, Compensation, and Liability Act (CERCLA). The proposed action would be conducted at Pit 9, Operable Unit 7-10, located at the Subsurface Disposal Area (SDA) of the Radioactive Waste Management Complex (RWMC) at the Idaho National Engineering Laboratory (INEL). The proposed action consists of construction of retrieval and processing buildings, excavation and retrieval of wastes from Pit 9, selectiva physical separation and chemical extraction, and stabilization of wastes either through thermal processing or by forming a stabilized concentrate. The proposed action would involve limited waste treatment process testing and full-scale waste treatment processing for cleaning up pre-1970 Transuranic (TRU) wastes in pit 9.

The purpose of this interim action is to expedite the overall cleanup at the RWMC and to reduce the risks associated with potential migration of Pit 9 wastes to the Snake River Plain Aquifer. Interim actions can be taken as a 
response to an immediate site threat or, as in the case of Pit 9, to facilitate the final cleanup of a site.

In accordance with CERCLA and the INEL Federal Facility Agreement and Consent Order (FFA/CO) signed on December 9, 1991, a revised Proposed Plan has been prepared that addresses the environmental impacts of this action. The Proposed Plan and a supplement (which provides additional information on cumulative impacts, endangered species, cultural resources, and occupational impacts for this action) constitute the Pit $9 E A$. Although the EA demonstrates that the risks associated with the proposed action are low, DOE would continue to evaluate options to reduce risks further.

Based on the analysis presented in the EA, DOE has determined that the proposed action is not a major Federal action significantly affecting the quality of the human environment within the meaning of the National Environmental Policy Act (NEPA). Therefore, the preparation of an environmental impact statement (EIS) is not needed for this proposed project as the means of incorporating NEPA values into the CERCLA process, and the Department is issuing this finding of no significant impact. Nothing herein is intended to represent a statement on the legal applicability of NEPA to remedial or interim actions conducted under CERCLA.

FOR FURTHER INFORMATION CONCERNING THE PROPOSED ACTION, CONTACT:

Mr. Dennis Hurtt, Director of External Affairs

Idaho Operations Office

U.S. Department of Energy 785 DOE Place

Idaho Falls, ID 83402-1118

(208) $526-8101$ 
FOR FURTHER INFORMATION CONCERNING THE DIJE NEPA PROCESS, CONTACT:

Ms. Carol Borgstrom, Director

Office of NEPA Oversight, EH-25

U.S. Department of Energy

1000 Independence Avenue, S.W.

Washington, DC 20585

(202) 586-4600 or leave message at (800) $472-2756$

BACKGROUND: The INEL is located in southeastern Idaho and occupies approximately 2,305 square kilometers ( 890 square miles) of Federal 1 and administered by DOE. The nearest towns are Idaho Falls, Blackfoot, Pocatello, Arco, and Atomic City. The RWMC is located in the southwest corner of the INEL and has been used since 1952 for storage or disposal of radioactive wastes. Pit 9, located within the SDA of the RWMC, was opened in September 1967 and closed in June 1969. Wastes in Pit 9 include TRU waste generated at the Rocky Flats plant in Colorado, and additional wastes, including low-level radioactive waste, from generators located at the INEL. TRU waste is contaminated with alpha-emitting transuranilim radionuclides which have an atomic number greater than 92 and half-lives greater than 20 years. TRU waste is currently defined under DOE Order 5480.2 as waste containing concentrations greater than 100 nanocuries per gram. These wastes may also be contaminated with hazardous wastes.

In November 1989 , the INEL was placed on the CERCLA National Priorities List (NPL) because of past known releases of hazardous substances that may pose risks to human health and the environment. Under CERCLA, sites on the NPL must be evaluated and appropriate actions selected and implemented for reducing these risks. Pursuant to requirements of CERCLA, an FFA/CO was developed for the INEL and was signed by representatives of DOE, Region 10 of 
the Environmental Protection Agency (EPA), and the State of Idaho on December 9, 1991. This proposed action will be conducted in accordance with applicable provisions of the FFA/CO.

PROPOSED ACTION: As part of the proposed action, DOE would excavate and selectively retrieve wastes in Pit 9; use physical separation and chemical extraction technologies to separate and remove wastes containing greater than 10 nanocuries of TRU components per gram; thermally stabilize TRU contaminated wastes or form a stabilized concentrate; and decontaminate and remove remediation facilities. The objective of the separation technology is to concentrate the radioactive contaminants by chemical extraction or physical separation, with the aim of reducing the volume of waste requiring disposal. Both treatment processes described under the proposed action in the EA would remove volatile organic compounds. The thermal process is expected to destroy $99.99 \%$ of volatile organic compounds. The chemical treatment process is expected to remove $99 \%$ of all organic compounis. Both processes would stabilize concentrated wastes containing TRU compounds removed from treated wastes.

The proposed action would consist of two phases: (1) limited waste treatment process testing and (2) full-scale waste treatment processing for remediation. Treated Pit 9 wastes would be stored in storage modules already planned for the RWMC TRU Storage Area. DOE has determined that the environmental impacts of storing waste in these mc lules are insignificant, based on the analysis in the Environmental Assessment for the Retrieval and Re-Storage of Transuranic 
Storage Area Waste at the Idaho National Engineering Laboratory, DOE/EA-0692, May 1992.

Two teams of subcontractors would complete proof-of-process tests using surrogate wastes to demonstrate the ability of their proposed processing systems to meet specified treatment standards and be effective in protecting workers and the public. DOE would select one team to conduct the limited waste treatment process test and full-scale remediation based on successful completion of the proof-of-process test and other specific evaluation criteria.

The 1 imited waste treatment process test would demonstrate that all integrated systems would function as designed and demonstrate their reliability before full-scale remediation begins. The 1 imited waste treatment process test would be conducted at pit 9 using the actual equipment and facilities that would be used for full-scale remediation. The test would begin by first using surrogates of plutonium and americium Lefore a limited amount of wastes from Pit 9 are processed through the system. The final phase would be the fullscale remediation of pit 9 . Full-scale remediation would not occur until both the proof-of-process and 7 imited liaste treatment process test phases have been successfully completed and applicable cleanup criteria met.

The proposed action would take place within the existing fenced area at the RWMC. An estimated 14,000 cubic meters $(500,000$ cubic feet) of soil and materials contaminated with hazardous materials and transuranic wastes would be excavated from the pit using remotely-controlled excavation equipment 
within a double confinement building that would be constructed over Pit 9 to serve as a retrieval enclosure. A building for the waste treatment processes, including a thermal treatment unit, would be built adjacent to the Pit 9 double confinement building. Only material containing greater than 10 nanocuries of transuranium radionuclides (i.e. radionuclides with an atomic number greater than 92) per gram would be treated. Waste containing less than 10 nanocuries of transuranium radionuclides per gram would be returned to the pit without being treated. This interim action would reduce the volume of material returned to the pit by greater than $90 \%$. The amount of material to be treated is estimated to be 7,000 cubic meters $(250,000$ cubic feet). Extensive monitoring equipment for hazardous and radioactive material as well as robotics and remotely-operated equipment would be used in the remediation of Pit 9. A 5 hectares (13 acres) area would be fenced outside the existing fence at the RWMC for parking, storing equipment, and mobile laboratory and administrative facilities.

The design of the retrieval enclosure and associated waste handling equipment w uld minimize the complexity and expense of eventual decontamination and demobilization. Equipment and buildings constructed would be the property of the subcontractor, and eventual decontamination and demobilization would be the responsibility of the subcontractor. DOE would not assume ownership or liability for any of the subcontractor's buildings or equipment. Numerous control measures wolitd be included in the design and operating procedures for the remediation of Pit 9 . Although the EA demonstrates that the risks associated with the proposed action are low, DOE would continue to evaluate options to reduce the risks. 
ENVIRONMENTAL IMPACTS: Environmental impacts would result from ground disturbance and atmospheric emissions. During all operations, emission control systems would be used to keep releases of contaminants within levels prescribed by applicable State and Federal requirements. Coristruction and routine operational activities would proceed according to regulations established under the Occupational Safety and Health Act (29 CFR 1900-1999). Exposure to radioactivity would be as low as reasonably achievable in accordance with the radiation protection standards set forth in DOE Orders. The use of robotics and extensive monitoring equipment would minimize the potential risk to workers and the public. The proposed action would not adversely impact endangered species, critical habitats, environmentally sensitive areas, or biological or archaeological resources.

Air Quality and Health and Safety Risks: Routine Operations. Impacts to air quality from routine excavation and treatment of pit 9 wastes would be minor. Emissions would be well below applicable EPA National Ambient Air quality Standards and occupational exposure limits in DOE Order 5483.1A. Releases would be minimized by various control measures, including dust suppression and use of high-efficiency particulate air (HEPA) filters and other filtration (e.g., carbon bed) of airborne effluent from the retrieval enclosure. Doses to the public and workers from radionuclide releases would be well below limits set by the National Emissions Standards for Hazardous Air Pollutants (NESHAPS) and would be unlikely to result in any adverse health effects. During all retrieval and treatment activities, worker exposures to radiation would be strictly monitored and controlled and maintained as low as reasonabiy achievable. Conservative assumptions were used to estimate releases to the 
atmosphere during cleanup of the pit. When process information becomes available, a more detailed analysis of risks to workers would be conducted and presented in the Final Safety Analysis Report for the Pit 9 Excavation and Remediation.

Potential non-radiological hazardous constituent exposures to workers and the maximally exposed individual member of the general public (MEI) during waste retrieval and treatment result in hazard indices of $1.0 \times 10^{-4}$ and $3.0 \times 10^{-2}$ respectively, based on an exposure duration of one year. Hazard indices are indicators of health risks; a hazard index of less than 1 indicates that ambient concentrations of hazardous substances in the air would result in an acceptable noncarcinogenic health risk. No adverse health effects resulting from exposure to non-radiological hazardous constituents would be expected during the project campaign.

The total cancer risk (radiological and non-radiological) to each worker and the MEI from waste retrieval and treatment would be an incremental cancer risk, above background, of $1.6 \times 10^{-7}$ and $7.2 \times 10^{-8}$ fatal cancers per year, respectively. Up to 150 workers may be involved in remediation activities. No cancer fatalities would be expected as a result of the entire project campaign.

Potential Impacts of Accidents. Radiological and non-radiological impacts resulting from a spectrum of postulated accidents were evaluated in the EA, including: (1) fire in waste processing area, (2) criticality in waste processing area, and (3) criticality during waste excavation. All three 
accidents, as modeled, could result in acute health effects (including prompt fatalities) for workers. To reduce the probability and consequences of accidents, safety features would be designed into the process systems and various administrative controls would be implemented (e.g., limited access to the pit area, safety requirements). The double confinement pit enclosure, process design, use of robotics, remotely-controlled operating equipment, and extensive monitoring equipment would minimize the potential impacts of hypothetical accidents. The analysis of hypothetical accidents was based on conservative assumptions and will be refined when more is known about the process design.

(1) Fire in the Waste Processing Area: The primary concern associated with this accident is potential exposure to non-radiological hazardous constituents, such as mercury. If a fire occurs in the waste processing area when the maximum amount of material is exposed (probability between $1.0 \times 10^{-4}$ and $1.0 \times 10^{-6}$ per year), the hazard indices calculated for (a) RWMC workers at 100 meters, (b) a member of the public visiting the EBR-1 reactor, a historic landmark, and (c) a MEI, would be 200,200 , and 100 , respectively. Based on conservative estimates, inhalation exposures to the airborne contaminants could cause acute health effects, including the death of up to 30 workers. RWMC workers at $100 \mathrm{~m}$ could be exposed to a fatal dose of mercury vapors. For the other locations, exposures to mercury would be below the maximum concentration of $28 \mathrm{mg} / \mathrm{m}^{3}$ from which a person could escape without excape-impairing or irreversible health effects, per guidelines established by the National Institute for Occupational Safety and Health. 
The same three receptors, respectively, would receive a radiation dose of $15 \mathrm{mrem}, 0.15 \mathrm{mrem}$, and $0.085 \mathrm{mrem}$ of radiation dose from this accident scenario, none of which would be expected to cause any adverse health effects. The increased risk of fatal cancer to the worker at $100 \mathrm{~m}$, for instance, would be 6 in 1 million.

Based on conservatism in the analysis, the low estimated probability of occurrence, and the expectation that the probability and consequences of this accident would be reduced further during detailed design, the overall risks associated with this accident are small.

(2) Criticality in the Waste Processing Area: Impacts from a criticality in the waste processing area (probability between $1.0 \times 10^{-4}$ and $1.0 \times 10^{-6} \mathrm{per}$ year) would result in acute radiation effects to workers in the processing area and doses to individuals outside the facility from fission product releases. The estimated doses to workers at $10 \mathrm{~m}$ are approximately $900 \mathrm{rem}$, at $13 \mathrm{~m}$ are $500 \mathrm{rem}$, at $20 \mathrm{~m}$ are $200 \mathrm{rem}$, and at $100 \mathrm{~m}$ are $6 \mathrm{rem}$. Workers within about $13 \mathrm{~m}$ of the criticality would receive a fatal dose; however, no fatalities are expected to occur because the nearest workers would be in the control room $20 \mathrm{~m}$ from the processing facility. Nonetheless, exposures to workers (up to 30 ) outside the immediate area (13 m) could produce acute health effects and increased risk of cancer. The consequences of this scenario would be mitigated by using administrative controls to limit personnel access to the area and to limit the amount of plutonium and hazardous waste that would be in process in the building at any one time. 
Doses to the MEI $\left(5.8 \times 10^{-12} \mathrm{rem}\right)$ would not cause a significant increased risk of a fatal cancer ( 1 in 1 trillion). Doses to the worker and MEI from inhalation, air immersion, ground surface, and ingestion pathways would be far below levels expected to cause any adverse health effects (worker at $100 \mathrm{~m}$ would receive $\left.4.3 \times 10^{-2} \mathrm{mrem}\right)$.

There would be no releases of non-radiological, hazardous materials as a result of this hypothetical accident.

(3) Criticality During Waste Excavation: The consequences to the public and workers from this accident scenario would be similar to those from a criticaiity accident in the waste processing area as described above, but the probability of this accident happening is extremely low, less than 1 in a million. This accident requires sufficient plutonium to be encountered and combined during excavation to form a critical mass, which is highly unlikely because retrieved waste would not be accumulated during excavation, but rather, moved on to be processed.

Cumulative Impacts. Routine emissions from the proposed action would not combine with other INEL emissions to result in cumulatively significant impact. The incremental dose to the MEI from the proposed action, when added to projected doses from other activities at RWMC and the dose from al1 radioactive atmospheric releases from the INEL in 1990, would result in a total dose estimated to be less than 0.3 mrem per year, well below the annual 7 imit of 10 mrem to the public as specified in the NESHAPS, 40 CFR Part 61, and DOE Order 5400.5 . 
ALTERNATIVES TO THE PROPOSED ACTION: Four alternatives to the proposed action have been considered. The alternatives are:

- No action: Under the no action alternative, DOE would take no further action until the Pit 9 project is evaluated under CERCLA in a Record of Decision for remediation of Waste Area Group 7. The no action alternative would not reduce the potential for contaminant releases to groundwater and the environment.

- In-situ vitrification: In this process, the contaminated material would be heated to a melting temperature by placing electrodes in the ground around the waste mass and running an electric current between the electrodes. The soils and contaminants would undergo physical changes and decomposition reactions including thermal or chemical destruction. The mass would be allowed to cool and solidify to a solid, stable mass that has properties similar to glass. Gases would be collected in a hood placed over the zone and treated to prevent releases to the atmosphere. This technology would require extensive testing and development before using it on a full-scale remediation. The long term effectiveness of this technclogy is unknown.

- Ex-situ vitrification: This process comprises excavating and melting wastes in a rotary kiln or electric furnace to a glassy matrix and returning the glassy matrix to Pit 9. Organic chemicals would be destroyed. Radionuclides would be trapped in the matrix. This 
technology would require extensive testing and development before using it on a full-scale remediation.

- Complete removal, storage, and off-site disposal: This process comprises excavating all wastes in the pit, packaging for on-site storage pending availability of off-site treatment and disposal facilities. This alternative does not reduce the toxicity, mobility or volume of the waste through treatment in accordance with Section 121 (b) of CERCLA.

DETERMINATION: The selected interim action for reducing contamination in Pit $g$ in accordance with the $F F A / C O$ between DOE, Region 10 of the EPA, and the State of Idaho does not constitute a major Federal action significantly affecting the quality of the human environment within the meaning of NEPA. This finding of no significant impact is based on the analysis in the EA. Therefore, an EIS is not needed as the means of incorporating NEPA values into the CERCLA process.

Issued at Washington, D.C., this $29^{\text {th }}$ day of fuly, 1993.

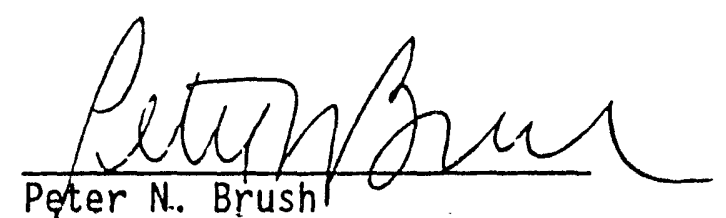

Acting Assistant Secretary

Environment, Safety and Health 
Supplement to the Revised Proposed Plan for a Cleanup of Pit 9 at the Radioactive Waste Management Complex, Idaho National Engineering Laboratory

June 3, 1993 


\section{CONTENTS}

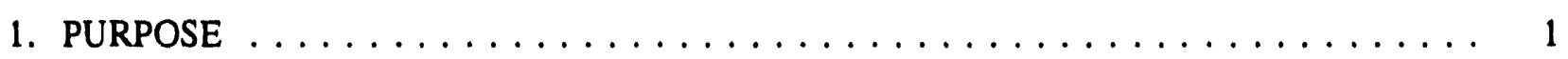

2. DESCRIPTION OF PROPOSED ACTION $\ldots \ldots \ldots \ldots \ldots \ldots \ldots \ldots \ldots$

3. DESCRIPTION OF THE AFFECTED ENVIRONMENT $\ldots \ldots \ldots \ldots \ldots \ldots \ldots$

4. ENVIRONMENTAL CONSEQUENCES OF THE PROPOSED ACTION $\ldots \ldots \ldots \ldots 4$

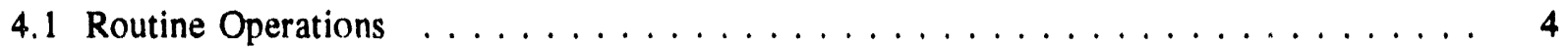

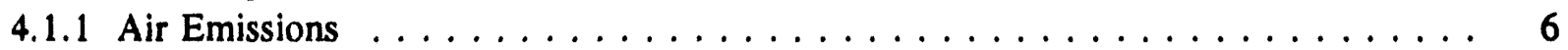

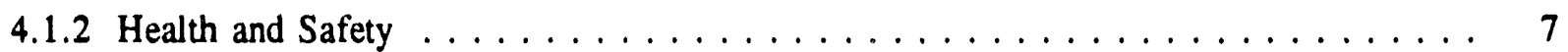

4.2 Potential Impacts of Accidents $\ldots \ldots \ldots \ldots \ldots \ldots \ldots \ldots \ldots$

4.2 .1 Fire in Waste Processing Area $\ldots \ldots \ldots \ldots \ldots \ldots \ldots \ldots \ldots \ldots \ldots \ldots$

4.2.2 Criticality in Waste Processing Area $\ldots \ldots \ldots \ldots \ldots \ldots \ldots \ldots \ldots \ldots \ldots \ldots \ldots \ldots$

4.2.3 Criticality During Waste Excavation $\ldots \ldots \ldots \ldots \ldots \ldots \ldots \ldots \ldots$

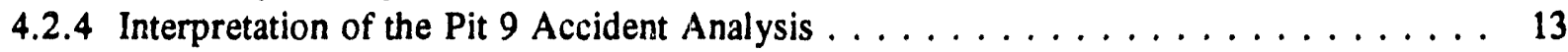

4.3 Cumulative Impacts of Routine Operations $\ldots \ldots \ldots \ldots \ldots \ldots \ldots \ldots \ldots$

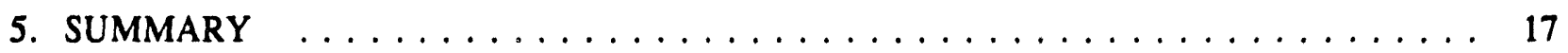

6. AGENCIES CONSULTED $\ldots \ldots \ldots \ldots \ldots \ldots \ldots \ldots \ldots \ldots \ldots \ldots \ldots$

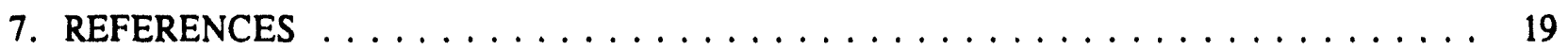

\section{FIGURES}

1. Map of RWMC facilities

\section{TABLES}

1. Summary of health risks associated with routine operations for cleanup of Pit $9 \ldots \ldots \ldots 8$

2. Health risks associated with particulate and gaseous releases during accident scenarios for cleanup

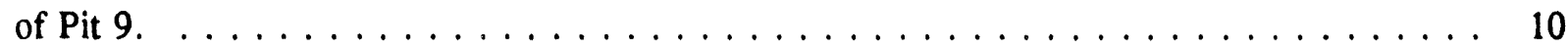

3. Prompt gamma and neutron doses from criticality accident $\ldots \ldots \ldots \ldots \ldots \ldots \ldots 12$

\section{APPENDIX A - HUMAN HEALTH RISK EVALUATION}




\section{Supplement to the Revised Proposed Plan for a Cleanup of Pit 9 at the Radioactive Waste Management Complex, Idaho National Engineering Laboratory}

\section{PURPOSE}

This document is a supplement to the Revised Proposed Plan for the Cleanup of Pit 9 at the Radioactive Waste Management Complex (RWMC), at the Idaho National Engineering Laboratory (INEL). This supplement evaluates potential environmental impacts associated with the cleanup of Pit 9 that were not presented in the Revised Proposed Plan. It is intended to incorporate the values of the National Environmental Policy Act of 1969 (NEPA), the council on Environmental Quality Regulations implementing NEPA, and the DOE NEPA Regulations (10 CFR 1021). Activities at Pit 9 would be conducted within interim action guidelines identified in the Code of Federal Regulations (CFR) 40 CFR Part 300 as the implementing regulations for the Comprehensive Environmental Response, Compensation, and Liability Act (CERCLA).

The scope of this supplement covers the excavation and the treatment of Pit 9 wastes only. This supplement does not cover the impacts associated with the construction of storage facilities needed for the transuranic wastes resulting from the treatment process. The storage modules to be used have been evaluated for environmental impacts in the Environmental Assessment for the Retrieval and ReStorage of Transuranic Storage Area Waste at the Idaho National Engineering Laboratory (DOE 1992a).

\section{DESCRIPTION OF PROPOSED ACTION}

The proposed action would comprise excavating and cleaning up Pit 9 at the RWMC at INEL. The action would be conducted in three phases: 1) proof-of-process tests, 2) limited production testing, and 3) full-scale production for remediation. The individual processes that would be utilized for this action have been demonstrated in other applications. The test phases would be performed within the interim action for Pit 9 before full-scale remediation to confirm that treatment standards could be met and to identify the most cost effective technique or combination of techniques for use in the remedial design. Both test phases must be successfully completed prior to full-scale remediation. The decontamination and demobilizing of equipment and buildings used during the proposed project would also be part of the proposed action.

The proof-of-process tests have been categorically excluded from further environmental review (Environmental Checklist/Categorical Exclusion RWMC-92-024) but are discussed here for explaining the complete interim action. The proof-of-process tests would demonstrate critical aspects and prove that the integrated processes to be used are effective in achieving cleanup goals. The tests must demonstrate ability of the chemical separation process(es) to perform as an integrated system at pilot or engineering scale for a minimum of 100 hours on a schedule that would be used for actual remediation. The thermal stabilization system and off-gas exhaust system must demonstrate ability to operate for a minimum of 100 hours on a schedule that would be used for actual remediation at a minimum feed rate of 136 to 227 kilograms (300 to 500 pounds) per hour. Surrogates of plutonium and americium would be used for the tests. 
The limited production test would demonstrate that all integrated systems would function as proposed and demonstrate reliability of the systems before full-scale remediation would begin. The limited production test would involve the same processes, area, and impacts as the remediation phase but on a smaller scale. Surrogates of plutonium and americium would be used initially in the test before materials from Pit 9 are processed through the system. The final phase would be full-scale remediation after successfully completing the limited production tests.

The proposed remedial action would take place within the existing fence at the RWMC. Pit 9 would be excavated within a double confinement building using remotely controlled excavation equipment. The building wouls contain remote radiological monitoring equipment and controls to minimize the chance of a criticality or any other radiation incident. Remote monitors would also be extensively used to ensure personnel protection from hazardous materials. A building for the waste treatment process and thermal unit would be built adjacent to the excavation building. This building would have high efficiency particulate air filters and other air emission control systems to ensure applicable air quality standards are met. An administrative area (previously categorically excluded), about 5.26 hectares ( 13 acres), would be fenced outside the existing fence at the RWMC for parking, equipment storage, and mobile laboratory and administrative facilities.

The design of the Pit 9 retrieval enclosure and associated waste handling equipment would minimize the complexity and expense of eventual decontamination and demobilization. The equipment and buildings constructed would be the property of the subcontractor, and eventual decontamination and demobilization would be the responsibility of the subcontractor. The U.S. Department of Energy (DOE) would not assume ownership of or liability for any of the contractor's buildings $c$ : equipment.

An estimated 14,160 cubic meters $(500,000$ cubic feet) of soil and other materials contaminated with hazardous materials and transuranic wastes would be excavated from the pit. Only material containing greater than 10 nanocuries per gram of transuranics would be treated. Waste containing less than 10 nanocuries per gram transuranics would be returned to the pit without being treated. The entire pit would be excavated, with materials heing segregated for treatment at the dig face by using radiation monitoring equipment for identifying materials containing greater than 10 nanocuries per gram. The amount of material containing more than 10 nanocuries per gram that would be treated is estimated to be 7,080 cubic meters $(250,000$ cubic feet $)$.

The sludge amounts disposed in Pit 9 (see page 3 of the Revised Proposed Plan) are composed of five types, or series (Series 741,742,743, 744, and 745), and were disposed in double polyethylene bags within 208-liter (55-gallon) drums. Series 741 and 742 sludges are wet sludges consisting of 50 to $70 \%$ water and precipitates of hydrated oxides of iron, magnesium, silicon, plutonium, and americium. Each drum of those two series was layered with 18 to 22.7 kilograms (40 to 50 pounds) of Portland cement for absorbing any free liquid. The consistency of the sludges is similar to packed earth.

The Series 743 sludge consists of a mixture of 114 liters (30 gallons) of organic liquid and 45.4 kilograms (100 pounds) of calcium silicate with 4.5 to 9 kilograms (10 to 20 pounds) of absorbent for absorbing oil. The organic liquid consists of about $47 \%$ lathe coolant $(60 \%$ Texaco Regal oil and $40 \%$ carbon tetrachloride), $10 \%$ degreasing agents (trichloroethane), and $43 \%$ miscellaneous organic compounds consisting of unspecified amounts of carbon tetrachloride, chloroethylenes, hydraulic oils, gear box oils, spindle oils, Freon, Varsol, and trace amounts of 
laboratory wastes (organophosphates, nitrobenzene). The Series 743 sludge has a consistency of wet pottery clay.

The Series 744 sludge consists of about 5.3 kilograms ( 26 pounds) of waste mixed with 86 kilograms (190 pounds) of Portland cement and 22.7 kilograms (50 pounds) of magnesia cement. The sludge consists of liquid wastes that were solidified because they could not be treated by carrier precipitation. The sludge is composed of chelating agents, organic acids, alcohols, etc., and has a consistency of hardened cement.

The Series 745 sludge consists of $60 \%$ sodium nitrate, $30 \%$ potassium nitrate, and $10 \%$ miscellaneous mass (e.g., gloves, rags, and paper). The Series 745 sludge has a consistency of dried water softener salt mixed with earth.

After treatment, the resulting waste stream would be stabilized either by casting as a slag in a thermal process, or by forming a stabilized concentrate containing nonvolatile organics, salts, heavy metals, and radionuclides. The stabilized material would be packaged into drums for storage as transuranic waste. Wastes requiring long-term storage would meet land disposal restrictions and would be stored in modules that meet applicable requirements of the Resource Conservation and Recovery Act (RCRA). The storage modules to be used have been evaluated for environmental impacts in the Environmental Assessment for the Retrieval and Re-Storage of Transuranic Storage Area Waste at the Idaho National Engineering Laboratory (DOE, 1992a).

Chemicals and liquids used in remediation would be recycled, thereby minimizing wastes from the process itself. Chemicals, liquids, filters, and other contaminated material left after the Pit 9 action is completed would be processed through the treatment system as a waste stream. The resulting waste would be stored as transuranic contaminated waste. There would be no liquids left from the process.

All equipment used for the interim action will be dismantled and removed from the site by the contractors when the action is completed, including any thermal treatment units. The site will be restored to a natural environment.

\section{DESCRIPTION OF THE AFFECTED ENVIRONMENT}

INEL is located in the cool, high desert environment in southeastern Idaho on the northeastern edge of the Eastern Snake River Plain approximately $95 \mathrm{~km}(59 \mathrm{mi})$ west of Idaho Falls, Idaho. It is primarily composed of silicic and basaltic rocks and relatively minor amounts of sediments. The Snake River Plain Aquifer underlies INEL and is designated a sole-source aquifer pursuant to the Safe Drinking Water Act. The depth to the aquifer varies from $61 \mathrm{~m}(200 \mathrm{ft})$ in the northern part of INEL to $274 \mathrm{~m}(900 \mathrm{ft})$ in the southern portion.

A series of basaltic lava flows with sedimentary interbeds underlie the RWMC. The basalts immediately beneath the site are relatively flat and covered by 6 to $9 \mathrm{~m}(20$ to $30 \mathrm{ft}$ ) of alluvium. The depth to the aquifer at the RWMC is $177 \mathrm{~m}(580 \mathrm{ft})$.

INEL is placed in Seismic Zone 2B (Uniform Building Code 1991), where moderate damage could be expected from a seismic event. Most surface water flow is from localized runoff, and no continuous surface water flows leave INEL (Finley, 1988). The RWMC, where Pit 9 is located, is 
not located within a 100-year floodplain. The dominant vegetation type is sagebrush-grass, with disturbed areas planted with crested wheatgrass.

No endangered species reside near the RWMC, and no known critical habitat exists in the area." Individual bald eagles and peregrine falcons may winter or pass through during migrations (Varacalle, 1988). An archaeological survey has been conducted ${ }^{\text {h }}$ and no culturally sensitive resources would be disturbed by the proposed action.

\section{ENVIRONMENTAL CONSEQUENCES OF THE PROPOSED ACTION}

This section discusses potential environmental impacts associated with the excavation and treatment of Pit 9 wastes. The Revised Proposed Plan, pages 7 to 10, evaluates environmental impacts of the alternatives. As noted in the Revised Proposed Plan, all activities would take place in previously disturbed areas. The action would not impact floodplains, wetlands, threatened or endangered species, sensitive habitats or environments, or cultural or historic resources.

Potential environmental impacts from the proposed action would be

- Impacts from air emissions

- Impacts to health and safety

- Potential impacts from accidents

- Cumulative impacts.

After remediation, Pit 9 would be closed in accordance with applicable requirements of RCRA (see page 11 of the Revised Proposed Plan). RCRA is an applicable or relevant and appropriate requirement for remediating Pit 9 under CERCLA. Final closure would be determitied in the Record of Decision for the Transuranic Pits and Trenches Remedial Investigation/Feasibility Study planned for July 1998.

\subsection{Routine Operations}

The proposed action includes provisions to protect workers and members of the public during routine excavation, retrieval, and waste treatment operations that would be conducted at Pit 9 . During all operations, air emission controlling systems would keep releases of contaminants to within applicable State and Federal requirements. Construction and routine operational activities would proceed according to regulations of the Occupational Safety and Health Act (OSHA) regulations (29

g. Letter from T. D. Reynolds to T. L. Perkins, "Threatened and Endangered Species Near the Radioactive Waste Management Complex," AM/EP-RESL-93-9, January 1993.

h. Letter from B. L. Ringe to K. B. Schuster, "Archaeological Clearance Recommendation for Project Activities within the Existing Fence at the Radioactive Waste Management Complex (RWMC) on the Idaho National Engineering Laboratory," BLR-02-93, January 5, 1993. 
CFR 1900-1999). Worker exposures would be in compliance with DOE and occupational safety requirements. Exposure to radioactivity would be as low as reasonably achievable and below the radiation protection standards set forth in DOE Orders. The use of robotics and extensive monitoring equipment would minimize the risk to workers and the public. The work environment would be monitored and personnel and area exposure monitoring data would be obtained to verify that workplace air contaminant levels are below those prescribed by the American Conference of Governmental Industrial Hygienists (ACGIH), OSHA, and applicable DOE standards.

To ensure regulatory compliance, the proposed action was evaluated for potential impacts and consequences that could result from routine operations associated with the cleanup of Pit 9 wastes.

The following assumptions were used to model releases during excavation (Staley 1992b, 1992c):

- $20 \%$ of the containers were breached at the time of disposal because of waste disposal practices used at the time Pit 9 was open.

- Container failure rate from corrosion for remaining containers is assumed to be $10.1 \%$ per year.

- Volatile organic compounds (VOCs) are uniformly distributed in the soil and have a linear concentration gradient.

- After excavation all VOCs in the soil are released.

- $\quad$ Radioactive decay for Pit 9 is corrected to 1992.

- $93 \%$ of radionuclide inventory is excavated.

- The particulate resuspension fraction is $0.1 \%$ (Elder et al., 1986).

- HEPA filtration efficiency is $99 \%$ for each of the two filters.

- Emissions were modeled as a stack release. The stack is assumed to be $15.2 \mathrm{~m} \mathrm{(50} \mathrm{ft)}$ high, $1.2 \mathrm{~m}(4 \mathrm{ft})$ in diameter, with an exit velocity of $20 \mathrm{~m} / \mathrm{s}(66 \mathrm{ft} / \mathrm{s})$.

- Workers are exposed $8 \mathrm{~h} / \mathrm{d}, 5 \mathrm{~d} / \mathrm{wk}, 50 \mathrm{wk} / \mathrm{y}$, or $2,000 \mathrm{hr} / \mathrm{y}$.

- The maximum exposed ir tividual (MEI) is an adult member of the public who is assumed to reside $365 \mathrm{~d} / \mathrm{y}$ at the INEL site boundary location where the maximum annual air concentration occurs, which is $5.9 \mathrm{~km}$ (3.7 miles) south-southwest of the RWMC.

- Other assumptions are described in Appendix A, Section A.3, "Impacts from Excavation."

The following assumptions were used to model releases during incineration (Staley, 1992a):

- Nonradiological releases from incineration would include criteria pollutants as products of combustion, hydrogen chloride from destruction of chlorinated hydrocarbons, and small quantities of volatile organic compounds not destroyed in the incinerator. 
- Radioactive components are treated as particulates and all are assumed to leave the combustion chamber of the incinerator in the offgas, to be filtered by the emission control system.

- The processing rate for waste is $7,000 \mathrm{~m}^{3} / \mathrm{y}\left(9,150 \mathrm{yd}^{3} / \mathrm{y}\right)$.

- Emission control efficiencies are listed in Appendix A, Table A-3.

- Stack parameters are $26.0 \mathrm{~m}(85.3 \mathrm{ft})$ high, diameter $0.30 \mathrm{~m}(1.0 \mathrm{ft})$, and exit velocity $42.0 \mathrm{~m} / \mathrm{s}(138 \mathrm{ft} / \mathrm{s})$.

- Workers are exposed $8 \mathrm{~h} / \mathrm{d}, 5 \mathrm{~d} / \mathrm{wk}, 50 \mathrm{wk} / \mathrm{y}$, or $2,000 \mathrm{hr} / \mathrm{y}$.

- The maximum exposed individual (MEI) is an adult member of the public who is assumed to reside $365 \mathrm{~d} / \mathrm{y}$ at the INEL site boundary location where the maximum annual air concentration occurs, which is $5.9 \mathrm{~km}$ (3.7 miles) south-southwest of the RWMC.

For routine operations radiological and nonradiological impacts were evaluated for a) a worker at $100 \mathrm{~m}$ (328 ft) from Pit 9; b) a member of the public visiting the Experimental Breeder Reactor I Historic Landmark, $2.9 \mathrm{~km}(1.8 \mathrm{mi})$ east northeast of the RWMC; and c) a member of the public at the nearest INEL site boundary, $5.9 \mathrm{~km}(3.7 \mathrm{mi})$ south southwest of the RWMC (see Sections A-1.i, A-1.2 of Appendix A). A minimum distance of $100 \mathrm{~m}$ (328 ft) is frequently used in environmental impact analysis modeling because Gaussian equations used in most dispersion codes are not intended, nor do they function properly, for determining impacts to people closer than $100 \mathrm{~m}$. Furthermore, elevated releases such as from high stacks or from lower stacks with high exit velocity will typically not reach ground level for a considerable distance downwind.

This evaluation is intended to provide a reasonable upper bound of potential impacts; therefore the source terms for activities are based on conservative assumptions. The activities that were evaluated were those associated with the excavation of material from Pit 9 and the incineration of the waste. Excavation was selected because it is common to both processes and could result in airborne emissions of radiological and nonradiological hazardous constituents. Incineration of the waste was evaluated because it provided a reasonable upper bound for the treatment processes under consideration. Sections 4.1 .1 and 4.1.2 identify the consequences of the routine operations.

\subsubsection{Air Emissions}

Airborne emissions of radiological and nonradiological hazardous constituents of retrieved wastes/soil, during both retrieval and treatment processes, would represent the greatest potential environmental impact from the proposed action. Modeling has been conducted to determine the potential impacts to air quality from waste retrieval and treatment (sec Sections A-1 to A-4 of Appendix $A$ for details and methods). This modeling determined that impacts to air quality from excavation and treatment of Pit 9 wastes would be well below applicable National Ambient Air Quality Standards and occupational exposure limits. Likewise, doses to the public and workers from radionuclide releases would be well below limits set by the National Emissions Standards for Hazardous Air Pollutants (NESHAPs) (see Sections A-1 to A-4 of Appendix A). Releases would be minimized by various control measures, including dust suppression and use of high-efficiency particulate air (HEPA) filters and other filtration (e.g., carbon bed) of airborne effluents from the retrieval enclosure. 
Confinement systems and contamination controls would be developed to minimize contaminant releases during the cleanup of the pit. Excavation of Pit 9 would take place within a double confinement structure. The operations and processes would be controlled remotely. Devices would be used to detect and monitor radioactive and hazardous materials within and around the buildings.

Conservative assumptions were used to estimate releases to the atmosphere when excavating the pit (see Section 3 and page 12 of the Revised Proposed Plan). Two HEPA filters were assumed for emissions calculations but more may be used during remediation. Also, air emissions control equipment such as activated carbon filters for removing volatile organic compounds are planned for actual operations but were not considered in emissions calculations. Each HEPA filter has a removal efficiency of $99.97 \%$, but $99 \%$ efficiency was assumed for the model. Similar constrvative assumptions were used to estimate releases from incineration of retrieved wastes and soll. This analysis is intended to determine the maximum potential risk. When process information becomes available, a detailed analysis of risks to workers would be conducted and presented in the Final Safety Analysis Report for the Pit 9 Excavation and Remediation.

\subsubsection{Health and Safety}

Estimated health risks to workers outside the retrieval enclosure $[100 \mathrm{~m}(328 \mathrm{ft})]$ and to the maximum exposed individual from routine Pit 9 operations are presented in Table 1. The maximum exposed individual is a hypothetical member of the public living at the nearest INEL boundary and who would receive maximum air concentrations of contaminants released from the proposed project (as identified by air dispersion modeling).

For the purpose of estimating the health and safety impacts of routine operations, hazard indices (HIs), nonradiological carcinogenic risks, and radiological cancer risk are used. Those exposed would include Pit 9 workers, other RWMC workers, maximum exposed individual at the INEL boundary, and general public. Hazard indices (HIs) [the sum of the hazard quotients (HQs) (EPA, 1989a)] for a remedial worker and for the maximally exposed (public) individual are listed in Table 1. Each HQ was calculated using one of two methods, depending upon the receptor. For the worker at $100 \mathrm{~m}(328 \mathrm{ft})$, the ambient concentrations of hazardous constituents were divided by apprupriate ACGIH threshold limit values (TLVs). For the MEI, the ambient concentrations of nonradiological hazardous constituents were divided by one-hundredth of the appropriate TLV, a guideline that the State of Idaho has recently set for granting permits to construct, modify, or operate air pollution sources (Idaho Air Quality Bureau, 1989).

A HI greater than 1 implies that the ambient concentration would result in an unacceptable health risk to workers or members of the general public at the exposure point. Conversely, a HI less than 1 implies that ambient concentrations of hazardous substances would result in an acceptable noncarcinogenic health risk at the exposure point. The HIs for the public and remedial workers from excavation and incineration for the Pit 9 cleanup are less than one. As with carcinogenic risks, the exposure duration is estimated to be for 1 year. 
Table 1. Summary of health risks associated with routine operations for cleanup of Pit 9.

\begin{tabular}{lcccccc}
\hline & \multicolumn{2}{c}{ Hazard Index } & \multicolumn{2}{c}{$\begin{array}{c}\text { Nonradionuclide Cancer Risk } \\
\text { (Per Person) }\end{array}$} & \multicolumn{2}{c}{$\begin{array}{c}\text { Radionuclide Cancer Risice } \\
\text { (Per Person) }\end{array}$} \\
\cline { 2 - 8 } Scenario & Worker & Public MEI & Worker & Public MEI & Worker & Public MEI \\
\hline Excavation & $3 \mathrm{E}-06^{\circ}$ & $1 \mathrm{E}-05$ & $1 \mathrm{E}-08$ & $2 \mathrm{E}-09$ & $2.8 \mathrm{E}-08$ & $3.3 \mathrm{E}-09$ \\
Incineration & $1 \mathrm{E}-04$ & $3 \mathrm{E}-02$ & $3 \mathrm{E}-10$ & $2 \mathrm{E}-09$ & $1.2 \mathrm{E}-07$ & $6.5 \mathrm{E}-08$ \\
Total & $1 \mathrm{E}-04$ & $3 \mathrm{E}-02$ & $1 \mathrm{E}-08$ & $4 \mathrm{E}-09$ & $1.5 \mathrm{E}-07$ & $6.8 \mathrm{E}-08$
\end{tabular}

a. Hazard indices are indicators of health risks. A hazard index less than 1 indicates that the concentration of hazardous substances in the air would result in no unacceptable noncarcinogenic health risk (EPA, 1989).

b. Based on a slope factor, which is a plausible upper bound estimate of the probability of a response per unit intake of a chemical over a lifetime. The slope factor is used to estimate an upper bound probability of an individual developing cancer as a result of a lifetime of exposure to a particular level of a potential carcinogen (EPA 1989).

c. Based on cancer risk factors of $4 \mathrm{E}-04$ and $5 \mathrm{E}-04$ fatal cancers/person-rem for workers and the public, respectively (NRC, 1991).

d. Maximum exposed individual (MEI).

c. To convert a number from scientific notation to its original form, multiply the base number times 10 raised to the given exponent. To convert 3E-06, multiply $3 \times 10^{-6}$, giving 0.000003 .

Total nonradiological carcinogenic risks were calculated for estimating above background probability of an individual developing cancer over a lifetime as a result of exposure to potential carcinogens and are calculated by summing carcinogenic risks from individual waste substances (EPA, 1989a). Individual waste substance risk3 are the product of the chronic daily intake of a waste substance and the slope factor (EPA, 1989a, 1989b). Slope factors represent an upper 95th percentile confidence limit of the probability of carcinogenic response based on experimental data used in a linear multistage model (EPA, 1989b). Radiological doses are presented as an effective dose equivalent (EDE) that include the committed EDE from internal deposition of radionuclides and the EDE resulting from penetrating radiation from sources external to the body. Committed EDEs are the sum of predicted dose equivalents to tissues and organs over a 50-y period after a known intake of a radionuclide into the body. The cancer risks were calculated using risk factors of $4 \mathrm{E}-04$ and $5 \mathrm{E}-04$ cancers/person-rem for workers and the public, respectively (NRC, 1991).

The following summarizes the risks identified from routine Pit 9 activities:

- Worker hazard index: The Hazard Index for workers from excavation is 3E-06 $(3 / 1,000,000)$ and from incineration is $1 \mathrm{E}-04(1 / 10,000)$ for a total $\mathrm{HI}$ of $1 \mathrm{E}-04$ $(1 / 10,000)$. The total $\mathrm{HI}$ is less than 1 which implies that routine activities would result in acceptable health risks.

- Worker cancer risk: The nonradiological cancer risk to the worker is IE-08 $(1 / 100,000,000)$ and radiological cancer risk is $1.5 \mathrm{E}-07(1.5 / 10,000,000)$ for a total cancer risk to the worker of $1.6 \mathrm{E}-07(1.6 / 10,000,000)$ from both excavation and incineration. 
- MEI hazard index: The MEI Hazard Index from excavation is $1 E-05(1 / 100,000)$ and from incineration is $3 E-02(3 / 100)$ for a total $\mathrm{HI}$ of $3 \mathrm{E}-02(3 / 100)$. The total $\mathrm{HI}$ is less than 1 which implies that routine activities would result in acceptable health risks.

- MEI Cancer Risk: The nonradiological cancer risk to the MEI is $4 \mathrm{E}-09(4 / 1,000,000,000)$ and radiological cancer risk is $6.8 \mathrm{E}-08(6.8 / 100,000,000)$ for a total cancer risk to the MEI of 7.2E-08 $(7.2 / 100,000,000)$ from both excavation and incineration.

Worker exposures to radiation under routine operations would be controlled under established procedures that require doses to be kept as low as reasonably achievable and that limit any individual's dose to less than $5 \mathrm{rem}(5,000 \mathrm{mrem})$ per year. Based on relevant experience with other projects, DOE expects doses from this proposed project to be maintained well below the limit on average. The annual estimated average dose is typical of thuse received by RWMC workers during recent years. The average estimated annual dose equivalent would be $39.7 \mathrm{mrem} /$ worker (range 0 to $251 \mathrm{mrem}$ ). The number of Pit 9 workers to be exposed in the course of normal operations would not exceed 150. Based on an occupational risk factor of $4 \times 10^{-4}$ fatal cancers per person-rem, or 1 fatal cancer per 2,500 person-rem, workers engaged in the proposed project would not be expected to incur any harmful health affects from radiation exposures they receive during normal operations. These doses can also be compared to the estimated annual dose to an individual living in southeast Idaho of $350 \mathrm{mrem} /$ year from natural background and medical radiation sources. EDEs to all receptors from routine activities would be below exposure levels expected to cause any adverse health effects and below doses received from background radiation in southeastern Idaho.

\subsection{Potential Impacts of Accidents}

The accident scenarios described in this document are taken from the Tentative Hazard Classification for Pit 9 (Reny, 1992). The accident scenarios in the hazard classification were selected to bound any remedial process that was chosen for Pit 9 . The assumptions on which the accidents were based were conservative in many respects and do not reflect the expected conditions when Pit 9 is remediated. The tentative hazard classification was prepared early in the project before the field of remedial technologies that could be used on the pit was narrowed to the two subcontractor proposals presented in the revised proposed plan.

The accident scenarios from the tentative hazard classification, and their bounding consequences are described in Section A-5 of Appendix A. In order to present a more realistic consequence evaluation of those accidents, each scenario was evaluated again and 2 of the 3 bounding assumptions listed below were changed to make the scenarios more realistic. The assumptions as modified still bound the remedial process.

- HEPA filters fail - In the re-evaluation it is assumed the HEPA filters do not fail.

- Large inventory of radioactive and hazardous waste available for release - This assumption was not changed in the re-evaluation of the accidents.

- The walls of the processing and excavation building are breached during the accident - In the re-evaluation it is assumed the walls of the processing and excavation building are not breached. 
It is assumed that due to the waste form, the lack of flammable material, and the fire suppression system, a fire in the process building would not generate sufficient heat to breach the facility walls or HEPA filters. The calculated energy from the postulated criticalities would not be sufficient to breach the containment or dislodge the HEPA filters. The accident scenarios described in this section were used to bound the consequences of Pit 9 remediation so that the proper design criteria and administrative controls would be used to prevent these accidents from ever occurring. Table 2 presents estimated health risks associated with the particulate and gaseous releases during hypothetical accidents.

In order to reduce the potential for and consequences of accidents to acceptable levels, safety features would be designed into the process systems and various administrative controls would be implemented (e.g., limited access, sarety requirements). The double contitzement, process design, use of robotics, remotely controlled operating equipment, and extensive monitoring equipment would minimize the likelihood of occurrence and potential impacts of hypothetical accidents. The analysis of hypothetical accidents will be refined when more is known about the process design.

Receptors evaluated for accident consequences are (a) the RWMC worker at $100 \mathrm{~m}$ (328 ft), (b) a member of the public visiting the EBR-1 reactor, a historical landmark $2.9 \mathrm{Km}(1.9 \mathrm{mi})$ east northeast of the RWMC, and (c) a member of the public at the nearest site boundary (NSB), which for Pit 9 is the same location as the MEl, $5.9 \mathrm{~km}(3.7 \mathrm{mi})$ south southwest of the RWMC. For the credible criticality accident, doses to workers closer than $100 \mathrm{~m}(328 \mathrm{ft})$ were also evaluated.

Table 2. Health risks associated with particulate and gaseous releases during accident scenarios for cleanup of Pit 9.

\begin{tabular}{|c|c|c|c|c|c|c|}
\hline \multirow[b]{2}{*}{ Scenario } & \multicolumn{2}{|c|}{ Worker at $100 \mathrm{~m}$} & \multicolumn{2}{|c|}{ EBR-1* } & \multicolumn{2}{|c|}{ NSB ${ }^{b}$} \\
\hline & $\operatorname{Dose}^{6}(\mathrm{mrem})$ & $\mathrm{HI}^{\circ}$ & Dose (mrem) & $\mathrm{HI}$ & Dose (mrem) & $\mathrm{HI}^{\bullet}$ \\
\hline Criticality in waste processing area & $4.3 \mathrm{E}-02$ & -1 & $3.9 \mathrm{E}-04$ & $-f$ & $3.3 E-04$ & $-f$ \\
\hline Fire in waste processing area & $1.5 \mathrm{E}+01$ & $2 E+02$ & $1.5 \mathrm{E}-01$ & $2 \mathrm{E}+02$ & 8.5E-02 & $1 E+02$ \\
\hline
\end{tabular}

a. Experimental Breeder Reactor I (EBR-I).

b. Nearest site boundary (NSB).

c. The committed effective dose equivalent from internal deposition of radionuclides and the effective dose equivalent from penetrating radiation from sources external to the body.

d. Millirem (mrem).

e. Hazard indices are indicutors of health risks. A hazard index less than 1 indicates that the concentration of hazardous substances in the air would result in no unacceptable noncarcinogenic health risk (EPA, 1989).

f. There would be no releases of nonradiological hazardous materials from this hypothetical accident, beyond those already being released from routine operations. 


\subsubsection{Fire in Waste Processing Area}

In this scenario, a fire is assumed to occur in the waste processing area when the maximum amount of material is exposed to fire risk. Conservatism built into this scenario is the assumption that the entire hazardous metal and asbestos inventory and a significant amount of the plutonium in the pit is available for release during this accident. This assumption does not take into account administrative controls that will place limits on the amount of plutonium and hazardous materials that would be in process in the building at any one time.

The fire is assumed to burn for one hour. The maximum amount of radioactive material in process at the time of a fire was determined by examining data on contents of Pit 9. A statistical analysis of disposal records has shown a probability of 1 chance in 1,000,000 that a localized region of Pit 9 containing $64 \mathrm{~m}^{3}\left(2,265 \mathrm{ft}^{3}\right)$ could contain as much as $5,300 \mathrm{~g}(11.7 \mathrm{lb})$ of plutonium (Wierman, 1991). Therefore, $5.300 \mathrm{~g}(11.7 \mathrm{lb})$ of plutonium was used for the initial calculation of source term.

Nonradioactive, hazardous materials were divided into metals and chlorinated hydrocarbons. Metals and asbestos are associated with waste thought to be located within specific regions of Pit 9 . To provide a bounding scenario, it is assumed that the entire inventory of any of these materials could be processed through the facility in a day. Beryllium has a very high melting point and is not present in dispersible form; therefore, a release fraction of $0.01 \%$ was used for this netal. Lead, which has a much lower melting point, was assigned a release fraction of $0.1 \%$. Mercury, which is volatile at standard temperature and pressure, is assumed to be $100 \%$ released. Finally, it is conservatively assumed that asbestos is present in dispersible form, with a release fraction of $1 \%$.

For chlorinated hydrocarbons, it is assumed that a full day's processing involves $13 \mathrm{~m}^{3}\left(17 \mathrm{yd}^{3}\right)$ of waste containing $30 \%$ Series 743 sludge, which in turn contains most of the inventory of chlorinated hydrocarbons. Chlorinated hydrocarbons are nonflammable and would vaporize when exposed to heat. Halogenated compounds break down with heat and fire, producing halogenated acids and phosgene-type compounds. For this analysis, it is assumed that $89 \%$ of chlorinated hydrocarbons would volatilize, $10 \%$ decompose to hydrochloric acid, and $1 \%$ decompose to phosgene gas.

HIs at the three locations, (100 m, EBR-1 reactor, and the nearest site boundary) are presented in Table 2. HIs for receptors at these locations would be greater than one, implying that unacceptable noncarcinogenic health risks would result from this accident. The receptors at 100 meters (RWMC workers), EBR-1 reactor (public), and the nearest site boundary (MEI) have HIs of 200, 200, and 100 respectively. A Hazard Index greater than 1 indicates that unacceptable health risks could result. Inhalation exposures of this magnitude to the airborne contaminants, for example, could cause cough, fever, nausea, vomiting, diarrhea, headache, and cardiac abnormalities. Symptoms could resolve, or progress to other complications resulting in death, depending on the length of exposure. Workers exposed at $100 \mathrm{~m}$ could be exposed to a fatal dose of mercury vapors. For the other receptor locations, exposures to mercury would be below the "Immediately Dangerous to Life and Health" (IDLH) level of $28 \mathrm{mg} / \mathrm{m}^{3}$. IDLHs are maximum concentrations from which one could escape without any escape-impairing or irreversible health effects (NIOSH, 1990).

Calculated EDEs, as a dose in mrem, to the three receptors from radiological releases are presented in Table 2. The receptors are workers at $100 \mathrm{~m}(328 \mathrm{ft})$, the general public, and the MEI located at NSB. A worker at $100 \mathrm{~m}(328 \mathrm{ft})$ would be expected to receive a radiation dose (EDE) of 15 mrem. EDEs to all receptors in this release scenario are below levels expected to cause any 
adverse health effects and are below doses received from background radiation in southeastern Idaho (350 mrem). None of the doses would result in adverse health effects; the increased risk of fatal cancer to the worker at $100-\mathrm{m}$, for instance, would be 6 in 1 million.

\subsubsection{Criticality in Waste Processing Area}

This accident scenario postulates that sufficient plutonium is encountered during waste processing and combined to form a critical mass. Because processing Pit 9 waste would "concentrate and change the form and content" of the waste, and because there is sufficient plutonium in Pit 9 $(18.7 \mathrm{~kg} ; 41.2 \mathrm{lb})$ to form a fissile mass, a nonexplosive, short-term, nuclear reaction (criticality) may be a credible accident (Reny, 1992). The criticality would be expected to take place during the plutonium separation process within the processing area. The scenario is described in Reny (1992). Based on guidance from Nuclear Regulatory Commission (NRC) Regulatory Guide 3.35 (NRC, 1979), it is assumed that a criticality occurs with an initial burst of $1 E+18$ fissions in 0.5 seconds. The consequences of this scenario would be mitigated by using administrative controls to limit personnel access to the area and to limit the amount of plutonium and hazardous waste that would be in process in the building at any one time.

Impacts from a criticality would be acute radiation effects to workers in the processing area and doses to individuals outside the facility from fission product releases. Prompt gamma and neutron doses from the criticality are described in Table 3 . Possible doses to workers at $10 \mathrm{~m}(32.8 \mathrm{ft})$ are

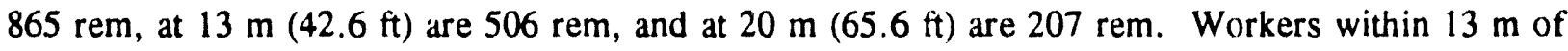
the criticality would receive a fatal dose. The 207 rem dose to a worker at $20 \mathrm{~m}(65.6 \mathrm{ft})$, could result in radiation sickness and an increased risk of fatal cancer of 8 in 100 . The dose to a worker at $100 \mathrm{~m}(328 \mathrm{ft}), 5.7 \mathrm{rem}$, would exceed the annual limit for radiation workers $(5 \mathrm{rem})$ specified in DOE Order 5480.11 and could result in higher than expected cancer incidence in that individual (increased risk of fatal cancer $=1$ in 500). Doses to the MEI at the nearest site boundary $(5.8 \mathrm{E}-12$ rem) would not cause a significant increased risk of a fatal cancer (increased risk to MEI receptor is less than 1 in 1 trillion). Remotely controlled operating equipment, the process design, and the use of extensive monitoring equipment would ieduce the probability of, and mitigate the consequences of a criticality accident. Administrative controls would be in place to limit personnel access to the waste processing area.

Table 3. Prompt gamma and neutron doses from criticality accident."

\begin{tabular}{lllllll}
\hline & \multicolumn{4}{c}{ Distance from Source of Criticality } \\
\cline { 2 - 7 } & \multicolumn{2}{c}{ Facility Workers } & & RHMC & & NSB \\
\cline { 2 - 7 } & $10 \mathrm{~m}$ & $13 \mathrm{~m}$ & $20 \mathrm{~m}$ & $100 \mathrm{~m}$ & $6000 \mathrm{~m}$ \\
\hline Total EDE $(\mathrm{rem})$ & 865 & 506 & 207 & 5.7 & $5.8 \mathrm{E}-12$
\end{tabular}

o. Reny, 1992

EDEs due to inhalation, air immersion, ground surface and ingestion pathways (Table 2) from this accident would be far helow levels expected to cause any adverse health effects. The dose to the worker at $100 \mathrm{~m}$ (4.3 E-02 mrem), for example, would result in an increased risk of a fatal cancer of 17 in 1 billion. There would be no releases of nonradiological, hazardous materials from this hypothetical accident, heyond those already being released from routine operations. 


\subsubsection{Criticality During Waste Excavation}

This accident scenario postulates that sufficient plutonium is encountered during excavation and combined to form a critical mass. This scenario is considered incredible because retrieved waste would not be accumulated during excavation, but rather, moved on to be processed. Thus, there is no "reasonably conceivable scenario" (Elder, 1986) during excavation for combining the necessary plutonium to form a critical mass. Excavation will be conducted using remote controlled equipment.

Impacts to near-in receptors from prompt gamma and neutron exposures from this criticality would be the same as that reported for the criticality in the waste processing area (Table 3). Workers within $13 \mathrm{~m}$ of the criticality would receive a fatal dose. Consequences from this scenario would be mitigated by design features and administrative controls.

EDEs due to inhalation, air immersion, ground surface and ingestion pathways from this accident would be about twice as high as those reported in Table 2 for the criticality in the waste processing area (see Section A-5.3 of Appendix A).

There would be no releases of nonradiological, hazardous materials from this hypothetical accident, beyond those already being released from routine operations (Table 1).

\subsubsection{Interpretation of the Pit 9 Accident Analysis}

The Pit 9 waste processing facility is classified as a moderate hazard facility according to DOE safety requirements. The probability of occurrence of the criticality and the fire in the waste processing area have not been determined precisely since a design is not yet available, but the probability of occurrence range is between $1 E-04$ and $1 E-06$ based on the tentative hazard classification.

The maximum number of workers estimated to be within 100 meters of the waste processing facility would be 30 . No workers would be expected to be allowed within the processing facility during operations. Maintenance would be performed within the facilities during shut down conditions. Of those 30 workers, 6 to 15 could be in the control room during operation, which is expected to be the only time a criticality could occur. A fire could occur whether the processing facility is operating or shut down. Any workers performing maintenance within the facility would be wearing personal protective equipment. The waste processing facility would be remotely operated from the control room, and would be located greater than 20 meters from the processing facility.

Based on this information and the conservative accident presented, up to 30 workers could receive a fatal exposure to mercury vapors from the fire in the waste processing area accident. The remaining receptors, which includes all expected workers at the RWMC (119 current RWMC workers plus Pit 9 workers and workers on other anticipated construction projects) would receive exposures less than the Immediately Dangerous to Life and Health (IDLH) concentration.

If the criticality accident occurred, all of the estimated 30 workers within 100 meters of the waste processing area would receive an estimated dose of at least $5.7 \mathrm{rem}$, which is greater than the DOE annual worker exposure limit of 5 rem, and could result in an increased risk of cancer of 1 in 500. The criticality in the waste processing area accident presented is estimated to result in a fatal dose only to workers within 13 meters of the source. 
Since the control room is expected to be located greater than 20 meters from the processing facility, no fatalities are expected to occur. Workers within 20 meters $(65.6 \mathrm{ft})$ would receive a 207 rem dose which could result in radiation sickness and an increased near-term risk of fatal cancer of 8 in 100 . Workers within the control room are outside of the 20 meter radius, so this would be an upper limit of exposure for those 6 to 15 workers.

Again, these risks are based on very conservative accident scenarios and limited design information. The estimated probability of occurrence and the impacts from the accidents would decrease as detailed design information becomes available.

\subsection{Cumulative Impacts of Routine Operations}

The proposed action is related to other actions under CERCLA at INEL as part of the Federal Facility Agreement/Consent Order. Other remedial projects probably will take place at the same time as this action at other waste area groups at INEL.

Four of the 14 operable units within Waste Area Group 7 at the RWMC are subject to the Remedial Investigation/Feasibility Study process. No other remedial actions are planned to occur at the same time within Waste Area Group 7. However, if another remedial action would take place at the same time, the two actions would be examined for cumulative environmental effect and measures would be taken to protect human health and the civvironment.

Total employment on remediation projects at INEL is estimated to not exceed 1,000 at any one time (the statement in the Revised Proposed Plan that 1,000 people would be employed at Waste Area Group 7 is in error).

Various facilities and activities have been planned or undertaken at the RWMC relating to retrieval, examination, repackaging, and storage of wastes. The facilities located at the RWMC include the Subsurface Disposal Area, the Transuranic Storage Area, and administrative facilities (see Figure 1). Existing buildings in the Transuranic Storage Area include the Certification and Segregation/Air Support Building 2 and the Stored Waste Examination Pilot Plant. Planned facilities include the Transuranic Storage Area Retrieval Enclosure, Waste Storage Facility, and Waste Characterization Facility.

Most of the exposure/dose information for routine facility operations at the RWMC was drawn from existing environmental documents (DOE, 1992a; Irving et al., 1991). External radiation exposures resulting from gamma radiation from waste containers were calculated for workers in the Stored Waste Examination Pilot Plant office building [approximately 440 meters $(1,444$ feet) southeast from Pit 9]. Detailed methodology is presented in DOE (1992a). The Stored Waste Examination Pilot Plant office building is used because, of all the office buildings at RWMC, it receives the highest cumulative gamma radiation dose from RWMC activities. The bounding annual occupational dose of 44 mrem to an office worker at the Stored Waste Examination Pilot Plant from gamma radiation is well below the DOE $100 \mathrm{mrem} / \mathrm{yr}$ limit for nonradiological workers and 5.0 rem limit for radiological workers. This dose is the total of the incremental gamma dose expected from Pit 9 operations and from the Certified \& Segregated Waste Storage/Air Support Building (see Section A-6 of Appendix A). 
The estimated EDE to the MEI at the INEL boundary from Pit 9 activities is 0.13 mrem (see Section A-4 of Appendix A). The largest potential dose from all other RWMC activities is 0.0004 mrem. Therefore, the cumulative EDE to the MEI at the RWMC from Pit 9 is 0.1304 mrem. The additional EDE of $0.1304 \mathrm{mrem}$ to the MEI from all waste retrieval and processing activities at RWMC (including Pit 9) would be below the 10-mrem/year standard of EPA (40 CFR 61) for members of the public.

No adverse health effects would be expected to result from the cumulative effects of RWMC operations combined with the proposed Pit 9 excavation and remediation activity.

Radiological and nonradiological impacts of atmospheric releases were added for all facilities for a worker exposed at 100 meters (328 feet) from the facilities and a MEI at the boundary of INEL [approximately 5.9 kilometers $(3.7$ miles) south-southwest from facilities at the RWMC]. The exposures to a worker at 100 meters (328 feet) are not actually additive because the 100-meter locations are different for each facility (see Section A-8 of Appendix A).

The Pit 9 project was also evaluated in term: of its cumulative impact on dose to the MEI from all INEL activities. The estimated EDE to a maximum exposed member of the public resulting from all radioactive atmospheric releases from INEL in 1991 was 0.004 mrem (DOE, 1992b). The additive dose from the Waste Experimental Reduction Facility, the Tank Farm replacement project at the Idaho Chemical Processing Plant, the Test Reactor Area Warm Waste Pond, and proposed RWMC activities (including Pit 9 excavation and remediation) was estimated to be $0.3 \mathrm{mrem} / \mathrm{y}$ or less (see Section A-6 of Appendix A). This is also within the 10-mrem/y standard of EPA (40 CFR 61). Doses from other facilities on INEL are not actually additive because the MEI locations are different for each facility (see Section A-6 of Appendix A). 


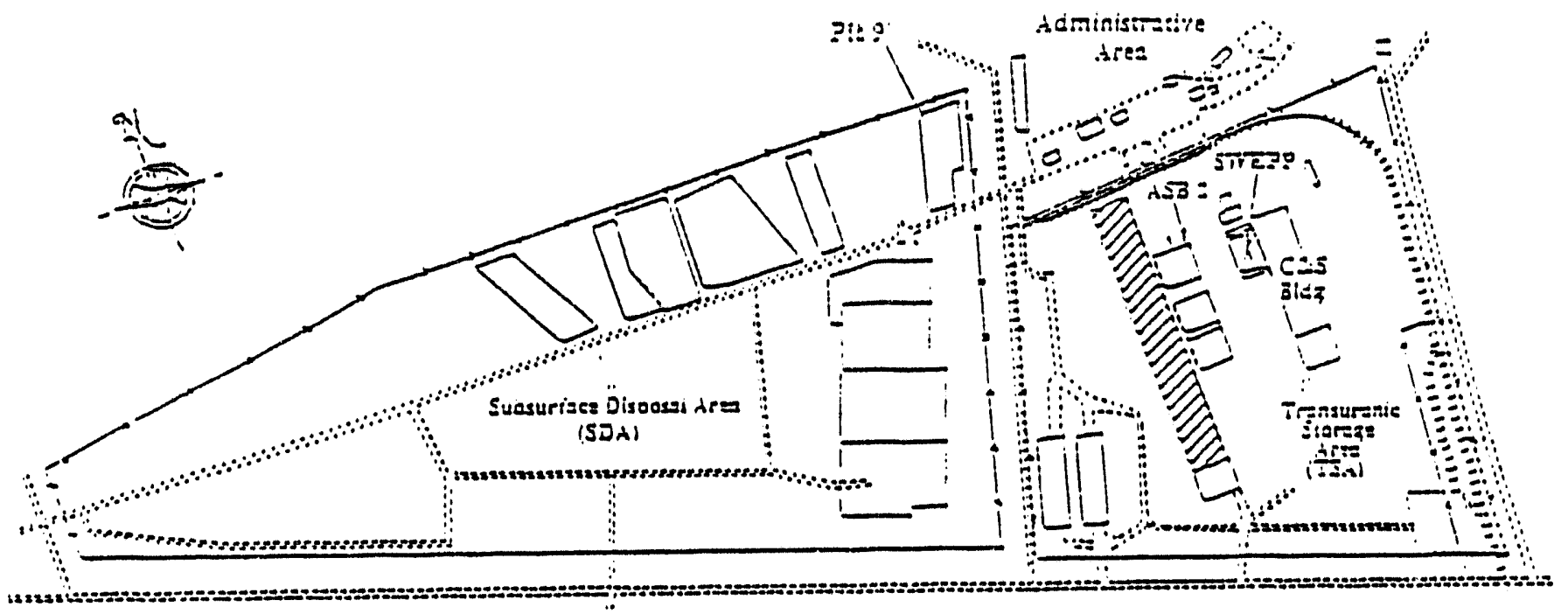

\section{Legend}

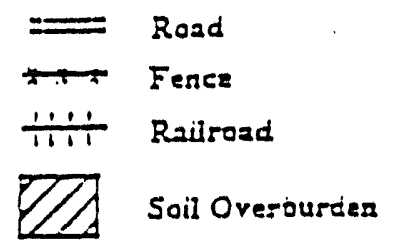

Figure 1. Map of RWMC facilities. 


\section{SUMMARY}

The Pit 9 excavation and remediation would not impact floodplains, wetlands, threatened or endangered species, sensitive habitats or environments, or cultural or historic resources. No adverse health effects would be expected as a result of the action. Airborne emissions of radiological and nonradiological hazardous constituents of retrieved wastes, during both retrieval and treatment processes, would represent the greatest potential environmental impact from routine operations. However, even with conservative assumptions used in release and dispersion calculations, the hazard indices for noncarcinogenic hazards would be below EPA acceptable limits. Carcinogenic risks from predicted exposures to emissions from Pit 9 excavation and remediation would be within EPA's threshold for acceptahle risk ( 1 per 10.000 people).

Doses from particulate and gaseous releases from the hypothetical accidents would not be expected to cause adverse health effects. Estimated releases of nonradiological, hazardous waste co:istituents from a fire could pose a short-term health risk (e.g., irritation of nose, throat, skin, and eyes, headache, nausea). However, no long-term health risks or fatalities would be expected from these short-term exposures. Potential radiological doses and exposures to nonradiological, hazardous releases from hypothetical accidents would be minimized through the use of administrative and operating controls, extensive monitoring of facility operations, and design features such as double confinement buildings and robotics.

Impacts from a criticality would be acute radiation effects to workers in the processing area and doses to individuals outside the facility from fission product releases. Prompt gamma and neutron doses from the criticality are shown in Table 3. Doses to workers within $13 \mathrm{~m}$ of the criticality could be fatal. The $207 \mathrm{rem}$ dose to a worker at $20 \mathrm{~m}(65.6 \mathrm{ft})$, could result in radiation sickness and an

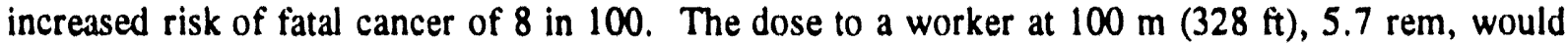
exceed the annual limit for radiation workers $(5 \mathrm{rem}$ ) specified in DOE Order 5480.11 and could result in higher than expected cancer incidence in that individual (increased risk of fatal cancer $=1$ in 500). Doses to the MEI at the nearest site boundary (5.8 E-12 rem) would not cause a significant increased risk of a fatal cancer (increased risk to MEI receptor is less than 1 in 1 trillion). Remotely controlled operating equipment, the process design, the use of extensive monitoring equipment, and administrative controls would mitigate the consequences of a criticality accident.

The additional EDE of 0.13 mrem (rounded to nearest hundred) to the MEI from all RWMC activities would be below the 10-mrem/year standard of EPA (40 CFR 61) for members of the public. For perspective, individuals in southeastern Idaho received an effective dose equivalent of 350 millirem in 1990 from natural background radiation sources (DOE, 1991). No adverse health effects would be expected to result from the cumulative effects of RWMC activities combined with the proposed Pit 9 excavation and remediation activity.

The Pit 9 project was also evaluated in terms of its cumulative impact on dose to the MEI from all INEL activities. The estimated EDE to a maximum exposed member of the public resulting from all radioactive atmospheric releases from INEL in 1991 was 0.004 mrem (DOE, 1992b). The additive dose from the Waste Experimental Reduction Facility, the Tank Farm replacement project at the Idaho Chemical Processing Plant, the Test Reactor Area Warm Waste Pond, and proposed RWMC activities (including Pit 9 excavation and remediation) was estimated to be $0.3 \mathrm{mrem} / \mathrm{y}$ or less (see Section A-6 of Appendix A). This is also within the 10-mrem/y EPA standard (40 CFR 61). 


\section{AGENCIES AND PERSONS CONSULTED}

The following agencies and persons were consulted during the preparation and review processes of the Revised Proposed Plan/Supplement for this interim action:

Threatened and endangered species:

C. Lobdell,

U.S. Fish and Wildlife Service,

(Species List SP\# 1-4-93-SP-84/506000, December 14, 1992)

Archeological/cultural resources clearance:

B. R. Ringe to S. Neitzel, Idaho State Historic Preservation Ottice, "Transmittal of Recommendation for Ground Disturbing Projects Within the RWMC Perimeter Fence on the INEL, "BLR-17-93 


\section{REFERENCES}

DOE 1992a, Environmental Assessment for the Retrieval and Restorage of Transuranic Storage Area Waste at the Idaho National Engineering Laboratory, U.S. Department of Energy, DOE/EA-0692.

DOE, 1992b, 1991 INEL National Emission Standard for Hazardous Air Pollutants Annual Report, DOE/ID-10342(915), U.S. Department of Energy, Idaho Field Office.

DOE, 1991, The Idaho National Engineering Laboratory Site Environmental Report for Calendar Year 1990. DOE/ID-12082(90).

DOE 5400.5 Radiation Protection of the Public and the Environment, June 5, 1990.

DOE 5480.23 Nuclear Safery Analysis Reports, April 301992.

DOE 6430.1A General Design Criteria, April 6, 1989.

Elder, J. C. et al., 1986, A Guide to Radlological Accident Considerations for Siting and Design of DOE Nonreactor Nuclear Facillties, Los Alamos National Laboratory, LA-10294-MS.

EPA, 1989a, Risk Assessment Guidance for Superfund, Volume 1, Human Health Evaluation Manual (Part A), EPA-540-1-89-002.

EPA, 1989b, Health Effects Assessment Summary Tables, Fourth Quarter FY 1989. OERR 9200.6-303-(89-4).Figueroa, I. del C., J. J. King, J. M. McCarthy, and Y. McClellan, 1992, Pit 9 Residual Risk Assessment, EG\&G Idaho, Inc., ERP-BWP-69.

Finley, K., 1988, Preliminary Environmental Analysis (PEA) for the TRA Liquid Radioactive Waste Clean-up, Phase III, EG\&G Idaho, Inc., December.

NRC, 1991, "Preamble to Standards for Protection Against Radiation," Nuclear Regulatory Commission, 56 FR 23363, May 21, 1991.

Idaho Air Quality Bureau, 1989, State of Idaho Guidance Manual for Obtaining a Permit to Construct, Modify or Operate an Air Pollution Source, Draft, October 1989.

Irving, J. S., M. G. Gratson, P. R. Leonard, S. J. Maheras, and C. S. Staley, 1991, Supplement Analysis of Transuranic Waste Characterization and Repackaging Activities at the Idaho National Engineering Laboratory in Support of the Waste Isolation Pilot Plant Test Program. EGG-EST-9346, May 1991.

McClellan, Y., I. del C. Figuerua, 1991, J. J. King, Preliminary Risk Evaluation for Pit 9, EGG-W M-9938.

NIOSH, 1990, Pocket Guide to Chemical Hazards, National Institute for Occupational Safety and Health. 
NRC (U.S. Nuclear Regulatory Commission), 1979, Assumptions Used for Evaluating the Potential Radlological Consequences of Accidental Nuclear Criticality in a Plutonium Processing and Fuel Fabrication Plant, Regulatory Guide 3.35, Revision 1, July.

Reny, D. A., T. E. Wierman, T. D. Enyeart, and D. L. Forsberg, 1992a, Tentative Hazard Classification for the Pit 9 Comprehensive Demonstration.

Staley, C. S., 1992a, Radiological and Non-Radiological Effects of Incinerating Retrieved Wastes from Pit 9. EG\&G Idaho Inc. Amended Engineering Design File No. RWMC-91-004.3.

Staley, C. S., 1992h, Hazardous Chemical Releases Resulting from Pit 9 Waste Retrieval at the RWMC, EG\&G Idaho Inc. Amended Engineering Design File No. RWMC-91-004.2, Revision 1.

Staley, C. S., 1992c, Radiological Impacts from Routine Operations of Pit 9 Waste Retrieval, EG\&G Idaho Inc. Amended Engineering Design File No. RWMC-91-004, Revision 1.

Uniform Building Code, International Conference of Building Officials, Whittier, CA., 1991.

Varacalle, D. J. 1988, Environmental Evaluation (EE) for the TRA Liquid Radioactive Waste Cleanup Phase III.

Wenzel, D. R., 1990, Interim Users Manual for RSAC-4 Radiological Safety Analysis Coniputer Program, Version 4.03, Westinghouse Idaho Nuclear Company, Inc. 


\section{Appendix A}

\section{Human Health Risk Evaluation}

June 3, 1993

A-1 


\section{CONTENTS}

Appendix A

A-1. RELEASES FROM EXCAVATION $\ldots \ldots \ldots \ldots \ldots \ldots \ldots \ldots \ldots \ldots$

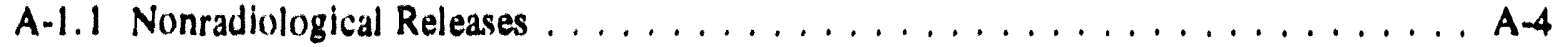

A-1.2 Radiological Releases . . . . . . . . . . . . . . . . . . . A-6

A-2. RELEASES FROM INCINERATION $\ldots \ldots \ldots \ldots \ldots \ldots \ldots \ldots \ldots$

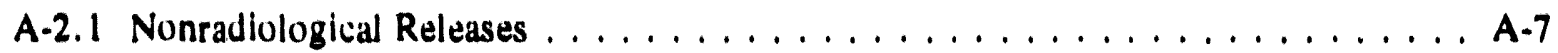

A-2.2 Radiological Releases $\ldots \ldots \ldots \ldots \ldots \ldots \ldots \ldots \ldots \ldots \ldots \ldots \ldots \ldots$

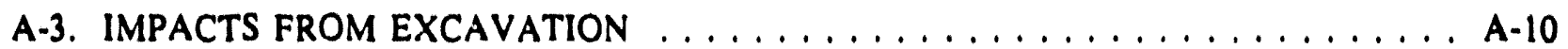

A-3.1 Nonradiological Impacts $\ldots \ldots \ldots \ldots \ldots \ldots \ldots \ldots \ldots \ldots \ldots$

A-3.2 Radiological Impacts $\ldots \ldots \ldots \ldots \ldots \ldots \ldots \ldots \ldots \ldots \ldots \ldots \ldots \ldots$

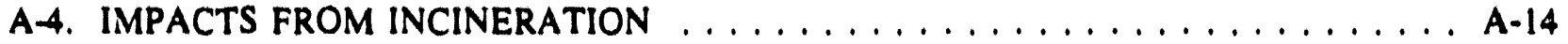

A-4.1 Nonradiological Impacts $\ldots \ldots \ldots \ldots \ldots \ldots \ldots \ldots \ldots \ldots \ldots \ldots \ldots$ A-14

A-4.2 Radiological Impacts $\ldots \ldots \ldots \ldots \ldots \ldots \ldots \ldots \ldots \ldots \ldots$ A-16

A-5. POTENTIAL ACCIDENTS AND CONSEQUENCES $\ldots \ldots \ldots \ldots \ldots \ldots \ldots \ldots$

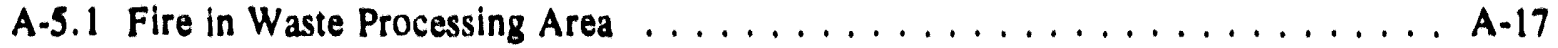

A-5.2 Criticality in Waste Processing Area . . . . . . . . . . . . . A-19

A-5.3 Criticality During Waste Excavation . . . . . . . . . . . . . . A-23

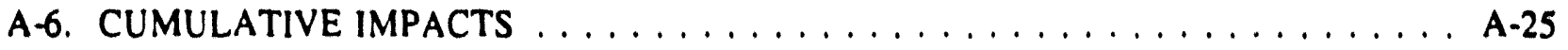

A.7. REFERENCES . . . . . . . . . . . . . . . . . . . . . . A-29 


\section{TABLES}

A-1. Estimated average air emission rates of hazardous constituents and resulting air concentrations at four receptor locations from routine Pit 9 retrieval $\ldots \ldots \ldots \ldots \ldots \ldots \ldots$

A-2. Calculated routine radionuclide releases from Pit 9 waste retrieval . . . . . . . . . . A-6

A-3. Incinerator and emission control system efficiencies and decontamination factors (DFs) . . A-8

A-4. Calculated release rates and air concentrations of nonradiological constituents at four receptor locations from incineration of Pit 9 wastes. Concentrations are hourly averages unless otherwise noted . . . . . . . . . . . . . . . . . . . . . . A $\ldots$

A-5. Calculated routine radionuclide releases from $P$ it 9 waste incineration . . . . . . . . A-10

A-6. HQs and HIs at three receptor locations as a result of routine hazardous chemical emissions from the proposed Pit 9 retrieval. $\ldots \ldots \ldots \ldots \ldots \ldots \ldots \ldots \ldots \ldots \ldots$. . . . . . . . .

A-7. Risks of additional cancers from individual hazardous chemicals and total carcinogenic risks at three receptor locations as a result of routine hazardous chemical emissions from the

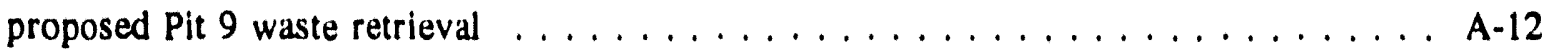

A-8. Estimated dose consequences to three receptor groups resulting from routine releases from Pit 9 waste retrieval . . . . . . . . . . . . . . . . . . . . . A 14

A-9. HQs and HIs at three receptor locations as a result of routine particulate emissions from Pit 9 waste incineration $\ldots \ldots \ldots \ldots \ldots \ldots \ldots \ldots \ldots \ldots \ldots \ldots \ldots$

A-10. Carcinogenic risks at three receptor locations as a result of routine emissions of asbestos and beryllium from Pit 9 waste incineration $\ldots \ldots \ldots \ldots \ldots \ldots \ldots \ldots \ldots$

A-11. Estimated dose consequences to three receptor groups resulting from routine releases from Pit

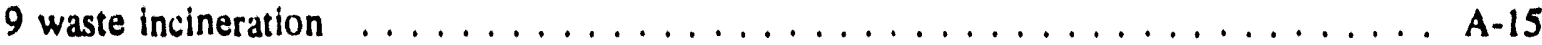

A-12. Releases and airborne concentrations of hazardous materials from a fire in the waste processing area $\ldots \ldots \ldots \ldots \ldots \ldots \ldots \ldots \ldots \ldots \ldots \ldots \ldots \ldots \ldots$

A-13. HQs and HIs from hazardous materials releases from a fire in the waste processing area . A-20

A-14. Radiological consequences (EDE, mrem) of a fire in the waste processing area . . . . . A A-20

A-15. Prompt gamma and neutron doses from criticality accident $\ldots \ldots \ldots \ldots \ldots \ldots$. . . . .

A-16. Radiological consequences (EDE, mrem) of criticality in the waste processing area . . . A-22

A-17. Radiological consequences (EDE, mrem) of a criticality during waste retrieval . . . . . A-24

A-18. HIs resulting from hazardous particulate releases (unmitigated scenario) from a criticality during waste retrieval $\ldots \ldots \ldots \ldots \ldots \ldots \ldots \ldots \ldots \ldots \ldots \ldots$

A-19. Estimated cumulative radiological doses from existing and proposed major INEL activities. A-27

A-20. Cumulative nonradiological impacts from activities related to transuranic retrieval from the Transuranic Storage Area at the RWMC . . . . . . . . . . . . . . . . . . A A-28 


\section{Appendix A}

\section{Human Health Risk Evaluation}

\section{A-1. RELEASES FROM EXCAVATION}

\section{A-1.1 Nonradiological Releases}

Releases of volatile organic compounds (VOCs) and hazardous particulate matter (e.g., ashestos, metals) could occur during excavation of wastes from Pit 9 at the Radioactive Waste Management Complex (RWMC). Release calculations for VOCs were based on a mathematical model developed for estimating the release and transport of chlorinated solvents in the vadose zone beneath hazardous waste sites (Walton et al., 1989). The model formulation accounts for container degradation, interphase mass transfer, waste decomposition, soil temperature erfects on physical and chemical properties of the waste, and mass transport through geologic media. Aqueous, nonaqueous, and vapor transport were considered. Calculations indicate the dominant transport mechanism is vapor diffusion to the surface and vadose zone. The key assumptions are

- $20 \%$ of containers were breached at the time of disposal. (The percent breached is assumed because of waste disposal practices used at the time Pit 9 was open for use.)

- Container failure rate from corrosion for remaining containers is $10.1 \%$ per year.

The model predicts concentrations of VOCs in the soil. For purposes of estimating VOC releases from Pit 9 retrieval, it is assumed that

- VOCs are uniformly distributed in soil and have a linear concentration gradient

- After excavation, all VOCs in the soil are released.

Releases of hazardous particulates were based on (a) Pit 9 inventory, (b) $93 \%$ of Pit 9 inventory is excavated in first year of retrieval [based on $90 \%$ of inventory being in south half of pit and $43 \mathrm{~m}^{3} / \mathrm{d}\left(56 \mathrm{yd}^{3} / \mathrm{d}\right)$ retrieval rate for $208 \mathrm{~d} / \mathrm{y}$ ), (c) particulate resuspension fraction of $1 \mathrm{E}-03$ (Elder et al. 1986), and (d) high efficiency particulate air (HEPA) filtration efficiency of $99 \%$ for each of the two filters. Mercury is considered a particulate release hecause it was disposed in liquid form and is assumed for this analysis to be absorbed onto soil particles. Release rates of nonradiological hazardous materials are summarized in Table $A-1$. The release point for the Pit 9 retrieval enclosure is assumed to be a $15.2 \mathrm{~m} \mathrm{(50} \mathrm{ft)} \mathrm{high,} 1.2 \mathrm{~m} \mathrm{(4} \mathrm{ft)} \mathrm{diameter} \mathrm{stack} \mathrm{with} \mathrm{an} \mathrm{exit} \mathrm{velocity} \mathrm{of} 20 \mathrm{~m} / \mathrm{s}$ (66 $\mathrm{ft} / \mathrm{sec})$. 
Table A-1. Estimated average air emission rates of hazardous constituents and resulting air concentrations at four receptor locations from routine Pit 9 retrieval.

\begin{tabular}{lccccc}
\hline & & \multicolumn{4}{c}{ Concentrations } \\
\cline { 3 - 6 } \multicolumn{1}{c}{ Constituent } & $\begin{array}{c}\text { Release rate } \\
(\mathrm{g} / \mathrm{s})^{2}\end{array}$ & $\begin{array}{c}\text { Worker } \\
\left(\mathrm{mg} / \mathrm{m}^{3}\right)\end{array}$ & $\begin{array}{c}\text { EBR-I } \\
\left(\mathrm{mg} / \mathrm{m}^{3}\right)\end{array}$ & $\begin{array}{c}\text { MEI/HWY } \\
\left(\mathrm{mg} / \mathrm{m}^{3}\right)\end{array}$ & $\begin{array}{c}\text { NAAQS } \\
\left(\mathrm{mg} / \mathrm{m}^{3}\right)\end{array}$ \\
\hline Carbon tetrachloride & $1.57 \mathrm{E}-03$ & $6.0 \mathrm{E}-05$ & $7.5 \mathrm{E}-06$ & $4.1 \mathrm{E}-06$ & - \\
Chloroform & $3.48 \mathrm{E}-04$ & $1.3 \mathrm{E}-05$ & $1.7 \mathrm{E}-06$ & $9.1 \mathrm{E}-07$ & - \\
Trichloroethylene & $5.16 \mathrm{E}-04$ & $2.0 \mathrm{E}-05$ & $2.5 \mathrm{E}-06$ & $1.3 \mathrm{E}-06$ & - \\
Perchloroethylene & $3.69 \mathrm{E}-04$ & $1.4 \mathrm{E}-05$ & $1.8 \mathrm{E}-06$ & $9.6 \mathrm{E}-07$ & - \\
$1,1,1-$ trichloroethane & $3.34 \mathrm{E}-04$ & $1.3 \mathrm{E}-05$ & $1.6 \mathrm{E}-06$ & $8.7 \mathrm{E}-07$ & - \\
Total VoCs & & $1.2 \mathrm{E}-04$ & $1.5 \mathrm{E}-05$ & $8.2 \mathrm{E}-06$ & $2.35 \mathrm{E}-01$ \\
Mercury & $1.55 \mathrm{E}-09$ & $5.9 \mathrm{E}-11$ & $7.4 \mathrm{E}-12$ & $4.0 \mathrm{E}-12$ & - \\
Lead & $1.09 \mathrm{E}-07$ & $4.1 \mathrm{E}-09$ & $5.2 \mathrm{E}-10$ & $2.8 \mathrm{E}-10$ & $1.5 \mathrm{E}-03$ \\
Asbestos & $4.66 \mathrm{E}-09$ & $1.8 \mathrm{E}-10$ & $2.2 \mathrm{E}-11$ & $1.2 \mathrm{E}-11$ & - \\
Lithium & $1.50 \mathrm{E}+00$ & $5.7 \mathrm{E}-12$ & $7.2 \mathrm{E}-13$ & $3.9 \mathrm{E}-13$ & - \\
Beryllium & $3.27 \mathrm{E}-09$ & $1.2 \mathrm{E}-10$ & $1.6 \mathrm{E}-11$ & $8.5 \mathrm{E}-12$ & - \\
Total Particulates & & $4.5 \mathrm{E}-09$ & $5.7 \mathrm{E}-10$ & $3.1 \mathrm{E}-10$ & $7.50 \mathrm{E}-02$
\end{tabular}

a. To convert a number from scientific notation to its original form, multiply the base number times 10 raised to the given exponent. To convert $3 \mathrm{E}-06$, multiply $3 \times 10^{6}$, giving 0.000003 .

Air concentrations of hazardous emissions at four receptor locations were calculated (see Table A-1) using dispersion factors $\left(\alpha / \mathrm{Qs}^{2}\right)$ calculated by the SCREEN model (Brodie, 1988). Emissions were modeled as a stack release using full meteorology and flat terrain. The receptor

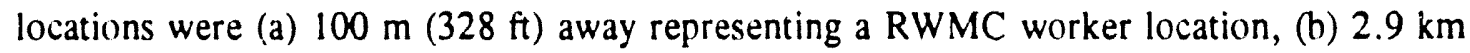
(1.8 miles) away at the Experimental Breeder Reactor I (EBR-I) site, where the public may visit, (c) $5.9 \mathrm{~km}$ (3.7 miles) northeast at the nearest public highway location, and (d) $5.9 \mathrm{~km}$ (3.7 miles) southsouthwest at the maximum exposed individual (MEI) location. ${ }^{b}$ The minimum distance of $100 \mathrm{~m}$ $(328 \mathrm{ft})$ is frequently used in environmental impact analysis because Gaussian equations used in most dispersion codes are not intended, nor do they function properly, for nearby dispersion calculations. Furthermore, elevated releases such as from high stacks, or from lower stacks with high exit velocity, will typically not reach ground level for a considerable distance downwind. Air concentrations at the nearest public highway and maximum INEL boundary would be the same (using the SCREEN model); thus, only one data set is presented.

a. The dispersion factor, $\chi^{/ Q}$ is defined as air concentration in $\mathrm{mg} / \mathrm{m}^{3}$, divided by the release rate in $\mathrm{mg} / \mathrm{s}$. Therefore, the product of release rate and $\chi / Q$ equals air concentration.

b. The MEI is a hypothetical member of the public who lives at the Idaho National Engineering Laboratory (INEL) boundary and who would be exposed to maximum air concentrations of contaminants released from the proposed project (as identified by air dispersion modeling). 
Concentrations are compared to applicable National Ambient Air Quality Standards (NAAQS), which have been adopted by the State of Idaho as the State's ambient air quality standards. There are no NAAQS for the other listed hazardous substances. The State of Idaho has proposed (January, 1993) standards for toxic air pollutants, but these are under review. EPA standards on National Emissions Standards for Hazardous Air Pollutants [NESHAPs (40 CFR 61)] for beryllium are intended for production facilities and do not apply to retrieval operations. While NESHAPs standards for asbestos are not directly applicable to waste retrieval, appropriate control measures would be used to minimize worker exposures and environmental releases. The data presented in Table A-1 indicate that air concentrations of hazardous chemicals resulting from emissions from Pit 9 waste retrieval would be well helow applicable regulatory air quality standards. Occupational Safety and Health Administration (OSHA) standards are the same as American Conference of Governmental Industrial Hygienists (ACGIH) Threshold Limit Value Short Term Exposure Limits (TLV-STELs), which have been incorporated in the calculation of hazard quotients and indices (see Section A-3).

\section{A-1.2 Radiological Releases}

In addition to releases of hazardous materials, routine waste retrieval would result in emissions of small quantities of radioactive materials to the atmosphere (Table A-2).

Table A-2. Calculated routine radionuclide releases from Pit 9 waste retrieval.

\begin{tabular}{lc} 
Radionuclide & $\begin{array}{c}\text { Release rate } \\
(\mathrm{Ci} / \mathrm{y})\end{array}$ \\
\hline Uranium-234 & $3.69 \mathrm{E}-07$ \\
Uranium-235 & $3.49 \mathrm{E}-10$ \\
Uranium-238 & $3.69 \mathrm{E}-07$ \\
Thorium-234 & $3.69 \mathrm{E}-07$ \\
Plutonium-238 & $2.37 \mathrm{E}-06$ \\
Plutonium-239 & $1.08 \mathrm{E}-04$ \\
Plutonium-240 & $2.46 \mathrm{E}-05$ \\
Plutonium-241 & $2.72 \mathrm{E}-04$ \\
Plutonium-242 & $1.17 \mathrm{E}-09$ \\
Americium-241 & $2.10 \mathrm{E}-04$ \\
Cobalt-60 & $1.24 \mathrm{E}-09$ \\
Cesium-137 & $2.39 \mathrm{E}-07$ \\
Barium-137m & $2.26 \mathrm{E}-07$ \\
Strontium-90 & $2.17 \mathrm{E}-07$ \\
Yttrium-90 & $2.17 \mathrm{E}-07$ \\
\hline
\end{tabular}

Key assumptions supporting radiological release calculations are similar to those for hazardous particulate releases (Section A-1.1): (a) $1992 \mathrm{Pit} 9$ inventory, (b) $93 \%$ of radionuclide inventory is excavated in first year of retrieval (based on $90 \%$ of inventory being in south half of pit and $43 \mathrm{~m}^{3} / \mathrm{d}$ $\left(56 \mathrm{yd}^{3} / \mathrm{d}\right.$ ) retrieval rate for $208 \mathrm{~d} / \mathrm{y}$ ), (c) particulate resuspension fraction of $1 E-03$ (Elder et al., 1986), and (d) HEPA filtration efficiency of $99 \%$ for each of the two filters. Emissions were modeled as a stack release. Effective dose equivalents (EDEs) resulting from these releases are presented in Section A-3.2. 


\section{A-2. RELEASES FROM INCINERATION}

\section{A-2.1 Nonradiological Releases}

Nonradiological releases from incineration would include criteria pollutants as products of combustion (both of wastes and propane, used to preheat and maintain the temperature of the incinerator), hydrogen chloride from destruction of chlorinated hydrocarbons, small quantities of VOCs not destroyed in the incinerator ( $99.99 \%$ destruction removal efficiency is assumed), and small quantities of metals that act as particulates. Release estimates are based on a maximum processing rate of $7,000 \mathrm{~m}^{3} / \mathrm{y}\left(9,150 \mathrm{yd}^{3} / \mathrm{y}\right)$ for $3.900 \mathrm{~h} / \mathrm{y}$; emission control system efficiencies as in Table A-3; and the following stack parameters: height $26.0 \mathrm{~m}(85.3 \mathrm{ft})$, diameter $0.30 \mathrm{~m}(1.0 \mathrm{ft})$, and exit velocity $42.0 \mathrm{~m} / \mathrm{s}(138 \mathrm{ft} / \mathrm{s})$. Calculated emission rates (see Table A-4) are based on the above parameters and soil concentrations presented in Staley (1992a).

\section{A-2.2 Radiological Releases}

Radioactive components of the retrieved wastes and soil are treated as particulates and all are assumed to leave the combustion chamber of the incinerator in the offgas, to be filtered by the emission control system (see Table A-3). Release rates (see Table A-5) are calculated based on the above assumptions and soil concentrations presented in Staley (1992b). 
Table A-3. Incinerator and emission control system efficiencies and decontamination factors (DFs).

\begin{tabular}{|c|c|c|c|c|c|c|c|}
\hline \multirow[b]{2}{*}{ Pollutant } & \multicolumn{2}{|c|}{ Quencher } & \multicolumn{2}{|c|}{ Venturi Scrubber } & \multicolumn{2}{|c|}{ HEPA $^{a}$ filter } & \multirow[b]{2}{*}{ Total DF } \\
\hline & $\begin{array}{l}\text { Percent } \\
\text { efficiency }\end{array}$ & DF & $\begin{array}{l}\text { Percent } \\
\text { efficiency }\end{array}$ & DF & $\begin{array}{l}\text { Percent } \\
\text { efficiency }\end{array}$ & DF & \\
\hline VOCs & & & & & & & $10,000^{b}$ \\
\hline \multicolumn{8}{|l|}{ Metals $^{\circ}$} \\
\hline Lead & & & 20 & 5 & $2 @ 90$ & 100 & 500 \\
\hline Asbestos & & & 20 & 5 & $2 @ 90$ & 100 & 500 \\
\hline Lithium & & & 20 & 5 & $2 @ 90$ & 100 & 500 \\
\hline Beryllium & & & 90 & 10 & $2 @ 95$ & 400 & 4000 \\
\hline Mercury & & & 20 & 5 & $2 @ 50$ & 4 & 20 \\
\hline Particulates $^{d}$ & 49 & 1.95 & 95 & 20 & $2 @ 99$ & 10000 & 393,000 \\
\hline Carbon monoxide & 0 & 1.00 & 0 & 1 & 0 & 1 & 1 \\
\hline Sulfur dioxide & 45 & 1.82 & 90 & 10 & 0 & 1 & 18.2 \\
\hline Nitrous oxides & 0 & 1.00 & 0 & 1 & 0 & 1 & 1 \\
\hline Hydrochloric acid & 47 & 1.89 & 99 & 100 & 0 & 1 & 189 \\
\hline \multicolumn{8}{|c|}{$\begin{array}{l}\text { a. High-efficiency air particulate. } \\
\text { b. } 99.99 \% \text { efficiency is assumed for destruction of VOCs by the incinerator. } \\
\text { c. Efficiencies from EPA (1989). } \\
\text { d. Particulates other than metals. }\end{array}$} \\
\hline
\end{tabular}


Table A-4. Calculated release rates and air concentrations of nonradiological constituents at four receptor locations from incineration of Pit 9 wastes. Concentrations are hourly averages unless otherwise noted.

\begin{tabular}{|c|c|c|c|c|c|}
\hline \multirow[b]{2}{*}{ Constituent } & \multirow[b]{2}{*}{$\begin{array}{l}\text { Release rate } \\
\qquad(\mathrm{g} / \mathrm{s})\end{array}$} & \multicolumn{4}{|c|}{$\begin{array}{c}\text { Concentration } \\
\left(\mathrm{mg} / \mathrm{m}^{3}\right)\end{array}$} \\
\hline & & $\begin{array}{l}100 \mathrm{~m} \\
\text { Worker }\end{array}$ & EBR-I & MEI/HWY & NAAQS \\
\hline \multicolumn{6}{|l|}{ VOCs } \\
\hline Carbon tetrachloride & $1.59 E-07$ & $1.26 \mathrm{E}-09$ & 4.33E-09 & $2.72 \mathrm{E}-09$ & - \\
\hline Chloroform & $3.54 E-08$ & $2.81 \mathrm{E}-10$ & $9.65 E-10$ & $6.05 E-10$ & - \\
\hline Trichloroethylene & $5.23 E-08$ & 4.16E-10 & $1.42 \mathrm{E}-10$ & $8.94 \mathrm{E}-10$ & - \\
\hline Perchloroethylene & $3.74 \mathrm{E}-08$ & $2.97 \mathrm{E}-10$ & $1.02 \mathrm{E}-09$ & $6.40 \mathrm{E}-10$ & - \\
\hline 1,1,1-trichloroethane & $3.39 E-08$ & $2.70 \mathrm{E}-10$ & $9.25 \mathrm{E}-10$ & $5.79 \mathrm{E}-10$ & - \\
\hline Total VOCs & & $2.53 E-09$ & $7.39 \mathrm{E}-09$ & $5.44 \mathrm{E}-09$ & $2.35 \mathrm{E}-01$ \\
\hline \multicolumn{6}{|l|}{ Particulates } \\
\hline Lead & $7.24 \mathrm{E}-04$ & $5.75 \mathrm{E}-06$ & $1.97 \mathrm{E}-05$ & $1.24 \mathrm{E}-05$ & $1.5 \mathrm{E}-03$ \\
\hline Asbestos & 3.10E-05 & $2.46 \mathrm{E}-07$ & $8.44 E-07$ & $5.30 \mathrm{E}-07$ & - \\
\hline Lithium & $1.00 \mathrm{E}-06$ & $7.94 \mathrm{E}-09$ & $2.72 \mathrm{E}-08$ & $1.71 \mathrm{E}-08$ & - \\
\hline Beryllium & $2.72 \mathrm{E}-06$ & $2.16 \mathrm{E}-08$ & $7.40 \mathrm{E}-08$ & $4.65 E-08$ & - \\
\hline Mercury & $2.59 \mathrm{E}-04$ & $2.06 \mathrm{E}-06$ & $7.05 E-06$ & 4.43E-06 & - \\
\hline From propane combustion & $1.14 \mathrm{E}-08$ & $9.06 \mathrm{E}-11$ & $3.10 \mathrm{E}-10$ & $1.95 \mathrm{E}-10$ & - \\
\hline Total Particulates & $1.01 \mathrm{E}-03$ & $6.03 \mathrm{E}-06$ & $2.77 \mathrm{E}-05$ & $1.74 \mathrm{E}-05$ & $7.50 \mathrm{E}-02$ \\
\hline \multicolumn{6}{|l|}{ Criteria Pollutants } \\
\hline Carbon monoxide & $1.18 \mathrm{E}+00$ & $9.40 \mathrm{E}-03$ & 3.22E-02 & $2.02 \mathrm{E}-02$ & $4.0 \mathrm{E}+01$ \\
\hline Sulfur dioxide ${ }^{a}$ & $4.00 \mathrm{E}-02$ & $1.42 \mathrm{E}-05$ & $4.85 \mathrm{E}-05$ & 3.03E-04 & $8.0 \mathrm{E}-02$ \\
\hline Nitrous oxides" & $9.05 E+00$ & $3.21 \mathrm{E}-03$ & 1. $10 \mathrm{E}-02$ & $6.86 E-03$ & $1.00 \mathrm{E}-01$ \\
\hline Hydrochloric acid & $5.74 \mathrm{E}-03$ & $4.56 \mathrm{E}-05$ & $1.56 \mathrm{E}-04$ & $9.80 \mathrm{E}-05$ & - \\
\hline
\end{tabular}


Table A-5. Calculated routine radionuclide releases from Pit 9 waste incineration.

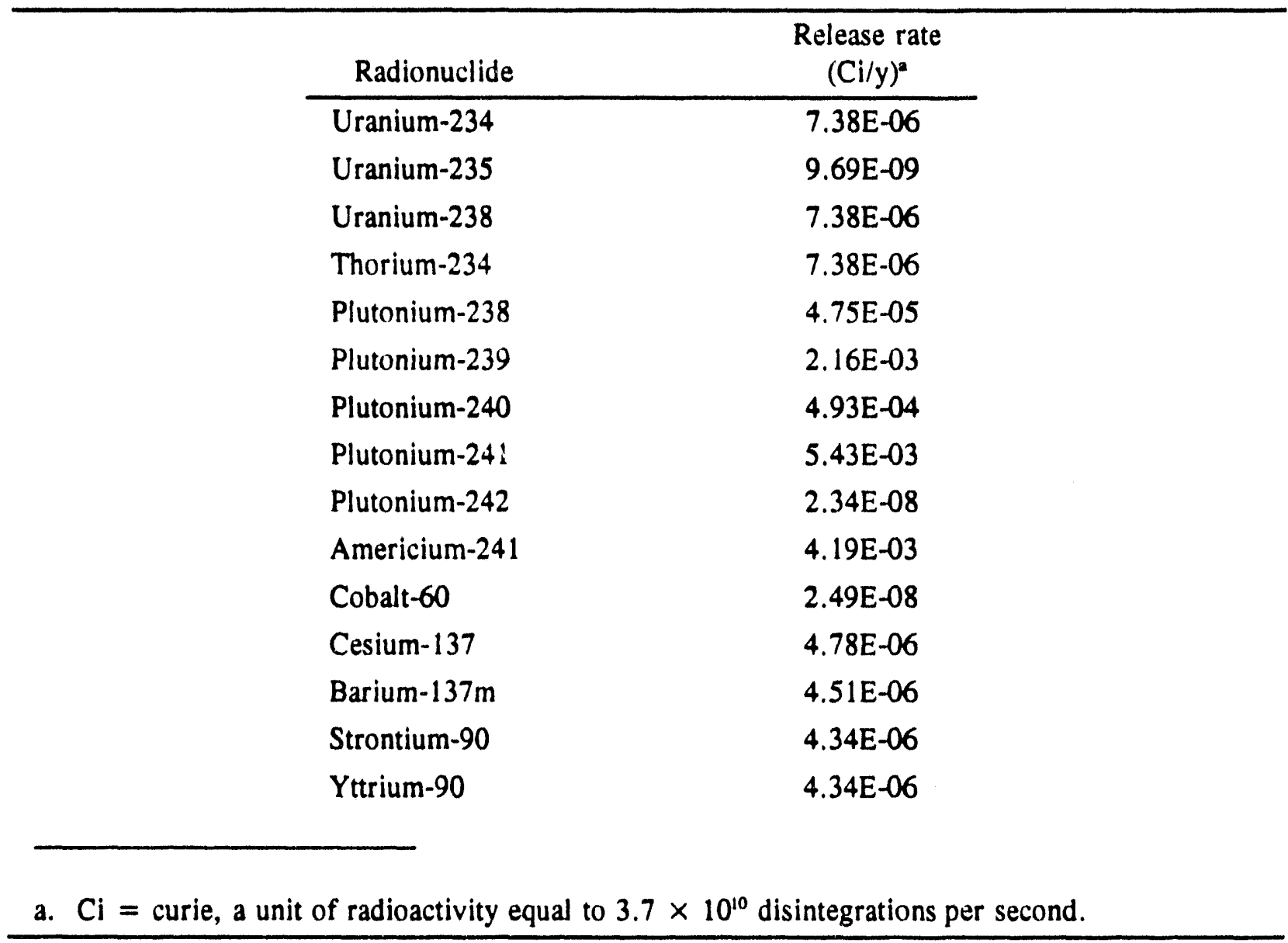

\section{A-3. IMPACTS FROM EXCAVATION}

\section{A-3.1 Nonradiological Impacts}

For the purpose of estimating the health and safety impacts of nonradiological airborne emissions from excavation, two methods were used:

1. Hazard indices $(\mathrm{HIs})^{\mathrm{c}}$ at the four locations were calculated by summing individual hazard quotients (HQs) d (EPA, 1989a). Each HQ was calculated using one of two methods, depending upon the receptor. For the worker at $100 \mathrm{~m}(328 \mathrm{ft})$, the ambient concentrations of hazardous constituents presented in Table A-1 were divided by appropriate ACGIH TLVs. For members of the public visiting EBR-I and at the INEL boundary, the ambient concentrations of nonradiological hazardous constituents in Table A-1 were divided by one-hundredth of the appropriate TLV, a guideline that the

c. Hazard Index (HI)-The sum of two or more hazard quotients for multiple substances and/or multiple exposure pathways.

d. Hazard Quotient (HQ)-The ratio of a single substance exposure level over a specified time period to a reference dose for that substance derived from a similar exposure period. 
sources (Idaho Air Quality Bureau, 1989). A HI greater thas 1 implies that the ambient concentration would result in an unacceptable health risk to workers or members of the general public at the exposure point. Conversely, a HI less than 1 implies that ambient concentrations of hazardous substances would result in an acceptable noncarcinogenic health risk at the exposure point. As with carcinogenic risks, the exposure duration is estimated to be for 1 year.

2. Total nonradiological carcinogenic risks were calculated for estimating above background probability of an individual developing cancer over a lifetime as a result of exposure to potential carcinogens and are calculated by summing carcinogenic risks from individual waste substances (EPA, 1989a). Individual waste substance risks are the product of the chronic daily intake of a waste substance and the slope factor (EPA, 1989a, 1989b). Slope factors represent an upper 95th percentile confidence limit of the probability of carcinogenic response based on experimental data used in a linear multistage model (EPA, 1989b).

Tables A-6 and A-7 present calculated HIs and cancer risks, ${ }^{\circ}$ respectively, for workers and members of the public resulting from emissions from the proposed treatment operations. HIs are at least four orders of magnitude (10,000 times) below one; thus, no unacceptable noncarcinogenic health risks are expected to result in air emissions from Pit 9 retrieval.

With respect to cancer risks, EPA (1989) has based the NESHAPs on assuring the increased lifetime cancer risk to an individual be no greater than 1 in 10,000 (1E-04). All cancer risk levels in Table A-7 are below this EPA criterion. Cancer risks from exposure to lead could not be calculated because EPA slope factors are not available. The compounds 1,1,1-trichloroethane, mercury, and lithium are not identified as human carcinogens. However, HQs for these constituents are all at least a factor of 300,000 below one; therefore, it is unlikely there would be a health risk associated with these low concentrations.

\section{A-3.2 Radiological Impacts}

The CAP-88 computer code (EPA, 1989c) was used to compute the EDE for (a) a RWMC worker located at $100 \mathrm{~m}$ from the proposed treatment facility, (b) the MEI located at the INEL boundary, $5.9 \mathrm{~km}$ (3.7 miles) south-southwest of the RWMC, and (c) the 1990 population living within $80 \mathrm{~km}(50 \mathrm{mi})$ of the RWMC. Doses were not modeled at EBR-I, located about $1.8 \mathrm{mi}$ from the RWMC, because members of the public at that location are transient visitors,

e. Risks of additional cancer above what would be expected in a normal population. 
Table A-6. HQs and HIs at three receptor locations as a result of routine hazardous chemical emissions from the proposed Pit 9 retrieval.

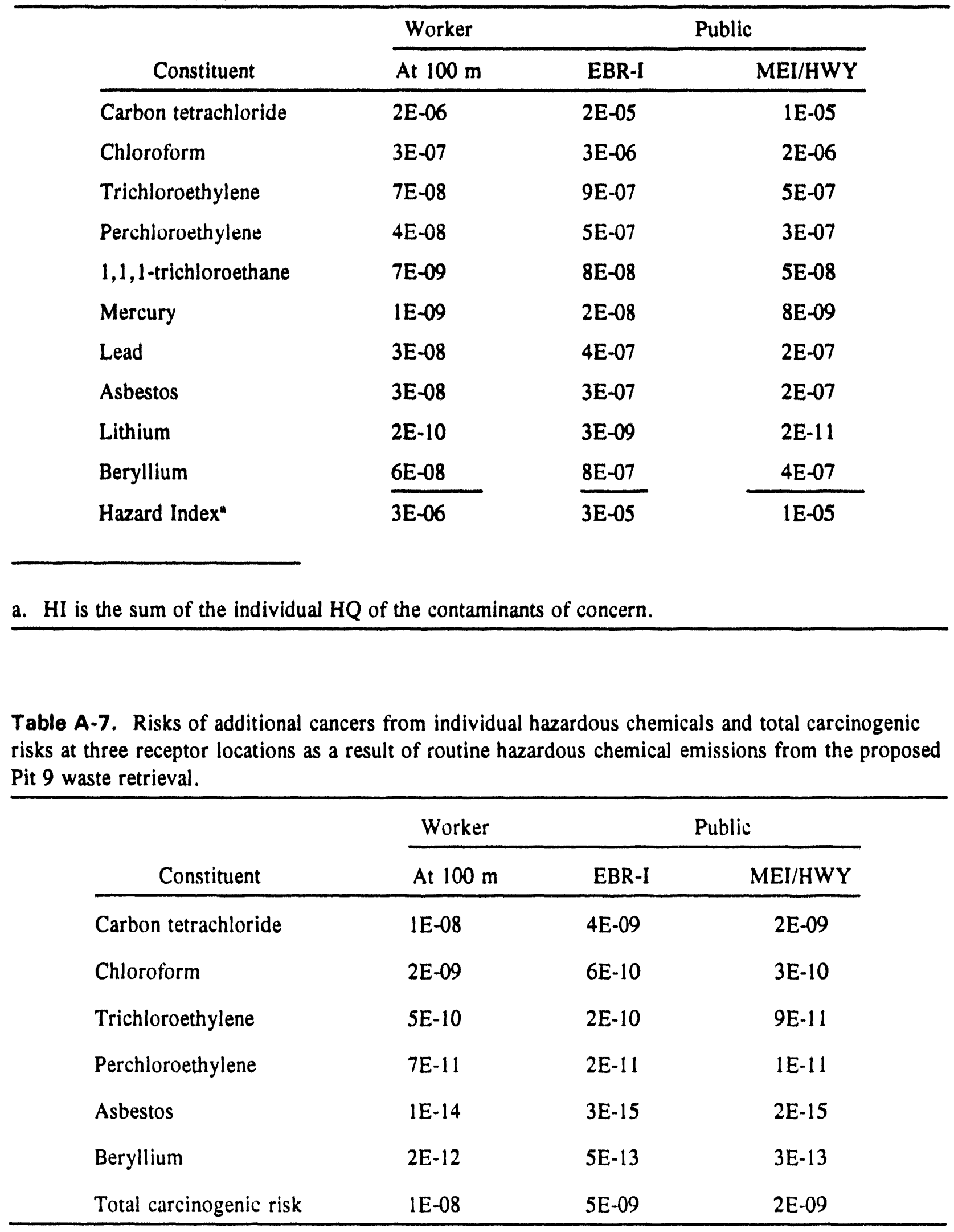


whereas the MEI is assumed to live and grow food at that location (see discussion below). Therefore, the dose to the MEI hounds the dose to the EBR-I visitor. The major assumptions and input data used in the CAP-88 runs were

- Five-year (1987-1991) meteorological frequency data collected from the CFA 10-m (33 ft) high meteorological tower were used to model atmospheric transport [CFA data have been determined by National Oceanic and Atmospheric Administration (NOAA) to be more reliable than RWMC datal. Calms were incorporated into the lowest wind speed class.

- The release point for the Pit 9 retrieval enclosure is assumed to be a $15.2-\mathrm{m}$ (50-ft) -high, $1.2-\mathrm{m}(4-\mathrm{ft})$-diameter stack with an exit velocity of $20 \mathrm{~m} / \mathrm{s}(66 \mathrm{ft} / \mathrm{s})$.

- Workers were assumed to be exposed $8 \mathrm{~h} / \mathrm{d}, 5 \mathrm{~d} / \mathrm{wk}, 50 \mathrm{wk} / \mathrm{y}$, or $2000 \mathrm{~h} / \mathrm{y}$, compared to $8766 \mathrm{~h} / \mathrm{y}$ for full-time occupancy. This work schedule is used routinely in radiological impact calculations. Workers do not incur an ingestion dose because they do not eat vegetables or animals grown in their respective locations (however, note that a small ingestion dose is incorporated in inhalation dose conversion factors used in CAP-88). Workers are further assumed to have a light activity breathing rate of $3.3 \mathrm{E}-04 \mathrm{~m}^{3} / \mathrm{s}$ (4.3E-04 $\left.\mathrm{yd}^{3} / \mathrm{s}\right)$ lor $2,400 \mathrm{~m}^{3} / \mathrm{y}\left(3,140 \mathrm{yd}^{3} / \mathrm{y}\right)$, compared to $8,030 \mathrm{~m}^{3} / \mathrm{y}\left(10,503 \mathrm{yd}^{3} / \mathrm{y}\right)$ for an average annual breathing rate that includes $8 \mathrm{~h}$ rest).

- The MEl is an adult member of the public who is assumed to reside $365 \mathrm{~d} / \mathrm{y}$ at the INEL site boundary location where the maximum annual air concentration occurs $15.9 \mathrm{~km}$ (3.7 mi) south-southwest of the RWMCl. This location was determined by a screening run. Dose to the MEI accounts for continuous exposure to inhalation, ground deposition, and immersion (cloud gamma). Ingestion dose assumes $70 \%$ of vegetables, $44 \%$ of meat, and $40 \%$ of the milk are locally grown or produced.

- $\quad$ The dose conversion factors used in the calculations were obtained from the CAP-88 RADRISK database (EPA, 1989c).

Doses are presented as EDE that include the committed EDE from internal deposition of radionuclides and the EDE resulting from penetrating radiation from sources external to the hody. Committed EDEs are the sum of predicted dose equivalents to tissues and organs over a 50-y period after a known intake of a radionuclide into the body. The cancer risks were calculated using risk factors of 4E-04 and 5E-04 cancers/person-rem for workers and the public, respectively (NRC, 1991).

Calculated EDEs resulting from a 1-year exposure to retrieval releases are summarized in Table A-8. The calculated EDE to the worker is far helow the $1,500 \mathrm{mrem} / \mathrm{y}$ as low as reasonably achievable (ALARA) goal at the RWMC. EDEs to the public are helow the NESHAPs (40 CFR 61) standard of $10 \mathrm{mrem} / \mathrm{y}$ for DOE facilities and below doses received from background radiation in southeastern Idaho lahout $350 \mathrm{mrem} / \mathrm{y}$ (DOE, 1992)]. For perspective, the dose to the $80 \mathrm{~km}(50 \mathrm{mi})$ population from background radiation is about 23,216 person-rem/y. No adverse health effects are anticipated from the low doses from retrieval operations. 


\section{A-4. IMPACTS FROM INCINERATION}

\section{A-4.1 Nonradiological Impacts}

Health effects from incinerator releases of VOCs were not calculated as for retrieval releases because air concentrations of VOCs released (see Table A-4) are far below those resulting from excavation (see Table A-1). Therefore, HIs and cancer risks for VOCs would be correspondingly lower and far helow levels of concern. HIs (see Tahle A-9) calculated for metal releases from the incinerator indicate that no unacceptable health risks to workers or the public would be presented by incineration of Pit 9 wastes. All cancer risk levels in Table A-10 are helow the EPA NESHAPs criterion of 1 in 10,000 .

Table A-8. Estimated dose consequences to three receptor groups resulting from routine releases from Pit 9 waste retrieval.

\begin{tabular}{llc}
\hline \multicolumn{1}{c}{ Receptor } & \multicolumn{1}{c}{$\begin{array}{c}\text { EDE } \\
(\mathrm{mrem} / \mathrm{y})\end{array}$} & $\begin{array}{c}\text { Additional lifetime } \\
\text { fatal cancer risk/yr }\end{array}$ \\
\hline Worker at $100 \mathrm{~m}(328 \mathrm{ft})$ & $6.9 \mathrm{E}-02$ & $3.5 \mathrm{E}-08$ \\
MEI & $6.6 \mathrm{E}-03$ & $3.3 \mathrm{E}-09$ \\
$80 \mathrm{~km}(50 \mathrm{mi})$ population & & $6.0 \mathrm{E}-06$
\end{tabular}

a. The project is planned to be completed in one year, therefore the cancer risk presented here equals the cancer risk for the life of the project.

b. 72,837 persons in 1990 .

Table A-9. HQs and HIs at three receptor locations as a result of routine particulate emissions from Pit 9 waste incineration.

\begin{tabular}{lllc}
\hline & \multicolumn{2}{c}{ Worker } & \multicolumn{2}{c}{ Public } \\
\cline { 2 - 4 } Constituent & At $100 \mathrm{~m}$ & EBR-I & MEI/HWY \\
\hline Mercury & $4 \mathrm{E}-05$ & $1 \mathrm{E}-02$ & $9 \mathrm{E}-03$ \\
Lead & $4 \mathrm{E}-05$ & $1 \mathrm{E}-02$ & $8 \mathrm{E}-03$ \\
Asbestos & $4 \mathrm{E}-05$ & $1 \mathrm{E}-02$ & $8 \mathrm{E}-03$ \\
Lithium & $3 \mathrm{E}-07$ & $1 \mathrm{E}-04$ & $7 \mathrm{E}-05$ \\
Beryllium & $1 \mathrm{E}-05$ & $\frac{4 \mathrm{E}-03}{3 \mathrm{E}-02}$ & $\frac{2 \mathrm{E}-03}{3 \mathrm{E}-02}$ \\
\cline { 2 - 4 } & Hazard index & &
\end{tabular}


Table A-10. Carcinogenic risks at three receptor locations as a result of routine emissions of asbestos and beryllium from Pit 9 waste incineration.

\begin{tabular}{lllc}
\hline & \multicolumn{2}{c}{ Worker } & \multicolumn{2}{c}{ Public } \\
\cline { 2 - 4 } Constituent & At $100 \mathrm{~m}$ & EBR-1 & MEI/HWY \\
\hline Asbestos & IE-11 & $1 \mathrm{E}-10$ & $8 \mathrm{E}-11$ \\
Beryllium & $3 \mathrm{E}-10$ & $3 \mathrm{E}-09$ & $2 \mathrm{E}-09$ \\
Total carcinogenic risk & $3 \mathrm{E}-10$ & $3 \mathrm{E}-09$ & $2 \mathrm{E}-09$ \\
\hline
\end{tabular}

Table A-11. Estimated dose consequences to three receptor groups resulting from routine releases from Pit 9 waste incineration.

\begin{tabular}{lll}
\hline \multicolumn{1}{c}{ Receptor } & \multicolumn{1}{c}{$\begin{array}{c}\text { EDE } \\
(\mathrm{mrem} / \mathrm{yr})\end{array}$} & $\begin{array}{c}\text { Additional fatal } \\
\text { cancer risk/yr }\end{array}$ \\
\hline Worker at $100 \mathrm{~m}(328 \mathrm{ft})$ & $3.0 \mathrm{E}-01$ & $1.5 \mathrm{E}-07$ \\
$\mathrm{MEl}$ & $1.3 \mathrm{E}-01$ & $6.5 \mathrm{E}-08$ \\
$80 \mathrm{~km}(50 \mathrm{mi})$ population & $2.6 \mathrm{E}-01$ (person-rem/yr) & $1.3 \mathrm{E}-04$ \\
& & \\
& & \\
a. The project is planned to be completed in one year, therefore the cancer risk presented here equals \\
the cancer risk for the life of the project. \\
b. 72,837 persons in 1990.
\end{tabular}




\section{A-4.2 Radiological Impacts}

EDEs from radiological releases from the incinerator were calculated similarly to those from excavation described in Section A-3.2 and are contained in Table A-11. Doses would be somewhat higher than those from excavation but still below standards and doses received from background radiation. It should be noted that doses estimated for incineration, as well as for waste retrieval, likely overestimate actual doses by a factor of at least 100, primarily hecause of conservative HEPA filter efficiencies and modeling assumptions used for the analysis.

\section{A-5. POTENTIAL ACCIDENTS AND CONSEQUENCES}

Potential consequences were evaluated for three hypothetical accidents: a) a fire in the waste processing area, determined to be a credible event (probability greater than or equal to 1 chance in $1,000,000$ per year, final absolute value to he determined); b) a criticality in the waste processing area, also a credible event; and c) criticality during retrieval, an incredible event (probability of less than 1 chance in $1,000,000$ per year).

The accident scenarios described in this document are taken from the Tentative Hazard Classification for Pit 9 (Reny, 1992). The accident scenarios in the hazard classification were selected to bound any remedial process that was chosen for Pit 9 . The assumptions on which the accidents were based were conservative in many respects and do not reflect the expected conditions when Pit 9 is remediated. The tentative hazard classification was prepared early in the project before the field of remedial technologies that could be used on the pit was narrowed to the two subcontractor proposals presented in the revised proposed plan.

In order to present a more realistic consequence evaluation of those accidents, each scenario was evaluated again and 2 of the 3 bounding assumptions listed below were changed to make the scenarios more realistic.

- HEPA filters fail - In the re-evaluation it is assumed the HEPA filters do not fail.

- Large inventory of radioactive and hazardous waste available for release - This assumption was not changed in the re-evaluation of the accidents.

- The walls of the processing and excavation huilding are breached during the accident - In the re-evaluation it is assumed the walls of the processing and excavation building are not breached.

Receptors evaluated for accident consequences are a) the RWMC worker at $100 \mathrm{~m}$, b) a member of the public visiting the EBR-I reactor, a historical landmark $2.9 \mathrm{~km}(1.9 \mathrm{mi})$ east northeast of the RWMC, and $c$ ) a member of the public at the nearest site houndary (NSB), which for Pit 9 is the same location as the MEI, $5.9 \mathrm{~km}(3.7 \mathrm{mi})$ south southwest of the RWMC. For the credible criticality accident, doses to workers closer than $100 \mathrm{~m}$ also were evaluated.

f. A criticality is defined as a non-explosive, short-term nuclear reaction. 


\section{A-5.1 Fire in Waste Processing Area}

In this scenario, a fire is assumed to occur in the waste processing area when the maximum amount of material is exposed to fire risk. The mitigated and unmitigated accidents were evaluated. Conservatism built into the accident scenario is the assumption that the entire hazardous metal and asbestos inventory and a significant amount of the plutonium in the pit is available for release during this accident. This assumption does not take into account administrative controls that would place limits on the amount of plutonium and hazardous materials that would be in process in the building at any one time.

The fire is assumed to hurn for one hour. The maximum amount of radioactive material in process at the time of a fire was determined by examining data on contents of Pit 9 . A statistical analysis of disposal records has shown a probability of 1 chance in $1,000,000$ that a localized region of Pit 9 containing $64 \mathrm{~m}^{3}\left(2,265 \mathrm{ft}^{3}\right)$ could contain as much as $5,300 \mathrm{~g}(11.7 \mathrm{lb})$ of plutonium (Wierman, 1991). Therefore, $5,300 \mathrm{~g}(11.7 \mathrm{lb})$ of plutonium was used for the initial calculation of source term.

Nonradioactive, hazardous materials were divided into metals and chlorinated hydrocarbons. Metals and asbestos are associated with waste codes thought to be located within specific regions of Pit 9. To provide a bounding scenario, it is assumed that the entire inventory of any of these materials could be processed through the facility in a day. Beryllium has a very high melting point and is not present in dispersible form; therefore, a release traction of $0.01 \%$ was used for this metal. Lead, which has a much lower melting point, was assigned a release fraction of $0.1 \%$. Mercury, which is volatile at standard temperature and pressure, is assumed to be $100 \%$ released. Finally, it is conservatively assumed that asbestos is present in dispersible form, with a release fraction of $1 \%$.

For chlorinated hydrocarbons, it is assumed that a full day's processing involves $13 \mathrm{~m}^{3}$ (17 $\left.\mathrm{yd}^{3}\right)$ of worst case waste containing $30 \%$ Series 743 sludge, which in turn contains most of the inventory of chlorinated hydrocarbons. Chlorinated hydrocarbons are nonflammable and would vaporize when exposed to heat. Halogenated compounds break down with heat and fire, producing halogenated acids and phosgene-type compounds. For this analysis, it is assumed that $89 \%$ of chlorinated hydrocarbons would volatilize, $10 \%$ decompose to hydrochloric acid, and $1 \%$ decompose to phosgene gas.

Maximum airhorne concentrations at the three receptor locations of nonradioactive, hazardous materials released from this fire, for both release scenarios, are presented in Table A-12. HIs at the three locations are presented in Table A-13. HIs for all receptors, for both release scenarios, would be greater than one, implying that unacceptable noncarcinogenic health risks would result from this accident. 
Table A-12. Releases and airborne concentrations of hazardous materials from a fire in the waste processing area.

\begin{tabular}{|c|c|c|c|c|c|c|c|c|c|}
\hline \multirow[b]{2}{*}{ Constituent } & \multirow{2}{*}{$\begin{array}{c}\text { Release } \\
\text { rate }(\mathrm{g} / \mathrm{s})\end{array}$} & \multicolumn{3}{|c|}{$\begin{array}{l}\text { Unmitigated release } \\
\qquad\left(\mathrm{mg} / \mathrm{m}^{3}\right)\end{array}$} & \multirow{2}{*}{$\begin{array}{l}\text { Release } \\
\text { rate }(g / s)\end{array}$} & \multicolumn{3}{|c|}{$\begin{array}{l}\text { Mitigated release } \\
\left(\mathrm{mg} / \mathrm{m}^{3}\right)\end{array}$} & \multirow{2}{*}{$\begin{array}{c}\mathrm{TLV} \\
\left(\mathrm{mg} / \mathrm{m}^{3}\right)\end{array}$} \\
\hline & & Worker & EBR-I & NSB & & Worker & EBR-I & NSB & \\
\hline $\begin{array}{l}\text { Carhon } \\
\text { tetrachloride }\end{array}$ & $6.75 E+02$ & $5.7 E+03$ & $2.7 \mathrm{E}+01$ & $1.3 \mathrm{E}+01$ & $6.75 E+02$ & $1.3 E+03$ & $1.4 \mathrm{E}+01$ & $7.4 \mathrm{E}+00$ & 12.6 \\
\hline $\begin{array}{l}1,1,1- \\
\text { trichloroethane }\end{array}$ & $2.33 E+02$ & $2.0 \mathrm{E}+03$ & $9.4 E+00$ & $4.5 E+00$ & $2.33 E+02$ & $4.6 E+02$ & $4.9 E+00$ & $2.6 \mathrm{E}+00$ & 1900 \\
\hline Trichloroethylene & $1.37 \mathrm{E}+02$ & $1.2 \mathrm{E}+03$ & $5.5 E+00$ & $2.6 \mathrm{E}+00$ & $1.37 \mathrm{E}+02$ & $2.7 E+02$ & $2.9 E+00$ & $1.5 \mathrm{E}+00$ & 270 \\
\hline Perchloroethylene & $1.52 \mathrm{E}+02$ & $1.3 \mathrm{E}+03$ & $6.1 E+00$ & $2.9 \mathrm{E}+00$ & $1.52 \mathrm{E}+02$ & $3.0 \mathrm{E}+02$ & $3.2 \mathrm{E}+00$ & $1.7 \mathrm{E}+00$ & 170 \\
\hline Hydrochloric acid & $1.21 \mathrm{E}+02$ & $1.0 \mathrm{E}+03$ & $4.9 E+00$ & $2.3 \mathrm{E}+00$ & $1.21 \mathrm{E}+02$ & $2.4 E+02$ & $2.5 \mathrm{E}+00$ & $1.3 \mathrm{E}+00$ & 7 \\
\hline Ashestos & $1.11 \mathrm{E}+00$ & $9.4 \mathrm{E}+00$ & $4.5 E-02$ & $2.1 E-02$ & $1.11 E-04$ & $2.2 \mathrm{E}-04$ & $2.4 \mathrm{E}-06$ & $1.2 \mathrm{E}-06$ & $6.7 E-03$ \\
\hline Beryllium & $5.56 \mathrm{E}-04$ & $4.7 \mathrm{E}-03$ & $2.2 \mathrm{E}-05$ & $1.1 \mathrm{E}-05$ & $5.56 \mathrm{E}-08$ & $1.1 \mathrm{E}-07$ & $1.2 E-09$ & $6.1 E-10$ & $2.0 \mathrm{E}-03$ \\
\hline Lead & $8.33 E-01$ & $7.1 E+00$ & $3.4 \mathrm{E}-02$ & $1.6 \mathrm{E}-02$ & 8.33E-05 & $1.7 E-04$ & $1.7 \mathrm{E}-06$ & $9.2 E-07$ & $5.0 \mathrm{E}-02$ \\
\hline Mercury & $2.78 \mathrm{E}-01$ & $2.4 \mathrm{E}+02$ & $1.1 \mathrm{E}+00$ & $5.3 \mathrm{E}-01$ & $2.78 E-01$ & $5.5 \mathrm{E}-01$ & $5.8 E-03$ & $3.1 E-03$ & $5.0 \mathrm{E}-02$ \\
\hline
\end{tabular}


In the unmitigated release, the $\mathrm{HI}$ to the worker was 7000 , to the public at EBR-1 was 3000 , and to the MEI at the NSB was 2000 . For the unmitigated release scenario, worker inhalation exposures of this magnitude to mercury, for example, could cause cough, fever, nausea, vomiting, diarrhea, headache, and cardiac abnormalities. Symptoms could resolve, or progress to other complications resulting in death.

In the mitigated release, the HI to the worker was 200, to the public at EBR-1 was 200, and to the MEI at the NSB was 100 . For the receptors exposures to mercury would be below the "Immediately Dangerous to Life and Health" (IDLH) level of $28 \mathrm{mg} / \mathrm{m}^{3}$. IDLHs are maximum concentrations from which one could escape without any escape-impairing or irreversible health effects (NIOSH, 1990).

Calculated EDEs to the three receptors from radiological releases are presented in Table A-14. Note that workers and members of the public visiting EBR-I would not incur an ingestion dose because they would not consume meat and vegetables grown at those respective locations. For the unmitigated release scenario, the EDE to the worker $(160 \mathrm{rem})$ would likely result in radiation sickness and a higher than expected cancer incidence (increased risk of fatal cancer $=6$ in 100) in that individual. Doses to the public receptors (760 and 1,200 mrem) would result in increased risks of fatal cancers of 4 in 10,000 and 6 in 10,000 for the EBR-I and NSB receptors, respectively. None of the doses from the mitigated release scenario would result in adverse health effects; the increased risk of fatal cancer to the $100-\mathrm{m}$ worker, for instance, would be 6 in 1 million.

\section{A-5.2 Criticality in Waste Processing Area}

Because processing Pit 9 waste would "concentrate and change the form and content" of the waste, and because there is sufficient plutonium in Pit $9(18.7 \mathrm{~kg} ; 41.2 \mathrm{lb})$ to form a fissile mass, a nonexplosive, short-term, nuclear reaction (criticality) may be a credible accident (Reny, 1992). The criticality would be expected 10 take place during the plutonium separation process within the processing area. The scenario is described in Reny (1992) and postulates a total yield of $1 E+18$ fissions occurring within a single burst of 0.5 second. This assumption is based on guidance from Nuclear Regulatory Commission (NRC) Regulatory Guide 3.35 (NRC, 1979). That guidance suggests one assume an initial burst of $1 E+18$ fissions in 0.5 seconds, followed successively at 10minute intervals by bursts of $1.9 \mathrm{E}+17$ fissions for one hour, for a total of $2.14 \mathrm{E}+18$ tissions. The initial burst of $1 E+18$ fissions would cause most of the dose from this accident.

Impacts from a criticality would be acute radiation effects to workers in the processing area and doses to individuals outside the facility from fission product releases. Prompt gamma and neutron doses from the criticality are described in Table A-15. Possible doses 
Table A-13. HQs and HIs from hazardous materials releases from a fire in the waste processing area.

\begin{tabular}{|c|c|c|c|c|c|c|}
\hline \multirow[b]{2}{*}{ Constituent } & \multicolumn{3}{|c|}{ Unmitigated release } & \multicolumn{3}{|c|}{ Mitigated release } \\
\hline & Worker & EBR-I & NSB & Worker & EBR-I & NSB \\
\hline Carbon tetrachloride & $5 E+02$ & $2 \mathrm{E}+02$ & $1 E+02$ & $1 E+02$ & $1 E+02$ & $6 \mathrm{E}+01$ \\
\hline 1,1,1-trichloroethane & $1 E+00$ & $5 \mathrm{E}-01$ & $2 \mathrm{E}-01$ & $2 \mathrm{E}-01$ & $3 E-01$ & $1 \mathrm{E}-01$ \\
\hline Trichloroethylene & $4 \mathrm{E}+00$ & $2 \mathrm{E}+\infty$ & $1 E+\infty$ & $1 E+\infty$ & $1 E+00$ & $6 \mathrm{E}-01$ \\
\hline Perchloroethylene & $8 E+00$ & $4 \mathrm{E}+\infty$ & $2 E+00$ & $2 \mathrm{E}+\infty 0$ & $2 E+00$ & $1 E+\infty$ \\
\hline Hydrochloric acid & $1 E+02$ & $7 E+01$ & $3 E+01$ & $3 E+01$ & $4 E+01$ & $2 \mathrm{E}+01$ \\
\hline Phosgene & $3 E+02$ & $2 \mathrm{E}+02$ & $8 E+01$ & $8 E+01$ & $9 E+01$ & $5 \mathrm{E}+01$ \\
\hline Asbestos & $1 E+03$ & $7 E+02$ & $3 E+02$ & $3 E-02$ & $3 E-02$ & 2E-02 \\
\hline Beryllium & $2 \mathrm{E}+00$ & $1 E+\infty$ & $5 \mathrm{E}-01$ & $6 E-05$ & $6 E-05$ & $3 E-05$ \\
\hline Lead & $1 E+02$ & $7 \mathrm{E}+01$ & $3 E+01$ & $3 E-03$ & $3 E-03$ & $2 \mathrm{E}-03$ \\
\hline Mercury & $5 E+03$ & $2 \mathrm{E}+03$ & $1 E+03$ & $1 E+01$ & $1 E+01$ & $6 \mathrm{E}+00$ \\
\hline Hazard index ${ }^{2}$ & $7 E+03$ & $3 E+03$ & $2 E+03$ & $2 E+02$ & $2 E+02$ & $1 E+02$ \\
\hline
\end{tabular}

a. The Hazard Index is the sum of hazard quotients (HQs) from individual waste constituents.

Table A-14. Radiological consequences (EDE, mrem) of a fire in the waste processing area.

\begin{tabular}{|c|c|c|c|c|c|c|}
\hline \multirow[b]{2}{*}{ Pathway } & \multicolumn{3}{|c|}{ Unmitigated release } & \multicolumn{3}{|c|}{ Mitigated release } \\
\hline & $\begin{array}{l}\text { Worker } \\
\text { at } 100 \mathrm{~m}\end{array}$ & EBR-I & NSB & $\begin{array}{c}\text { Worker at } \\
100 \mathrm{~m}\end{array}$ & EBR-I & NSB \\
\hline Inhalation & $1.6 \mathrm{E}+05$ & $7.6 \mathrm{E}+02$ & $3.6 \mathrm{E}+02$ & $1.5 \mathrm{E}+01$ & $1.5 \mathrm{E}-01$ & $8.1 E-02$ \\
\hline Air immersion & $2.1 E-03$ & $1.0 E-05$ & $4.8 E-06$ & $2.0 \mathrm{E}-07$ & $2.1 E-09$ & $1.1 \mathrm{E}-09$ \\
\hline Ground surface & $1.5 E+00$ & 7.1E-03 & 4.3E-03 & $1.4 \mathrm{E}-04$ & $1.4 \mathrm{E}-06$ & $7.6 \mathrm{E}-07$ \\
\hline Ingestion & $N A^{2}$ & $N A^{2}$ & $8.5 E+02$ & NA & NA & $3.9 E-03$ \\
\hline Total & $1.6 \mathrm{E}+05$ & $7.6 \mathrm{E}+02$ & $1.2 \mathrm{E}+03$ & $1.5 E-01$ & $1.5 \mathrm{E}-01$ & $8.5 \mathrm{E}-02$ \\
\hline
\end{tabular}

a. Workers and visitors to EBR-I would not incur an ingestion dose. 
Table A-15. Prompt gamma and neutron doses from criticality accident."

\begin{tabular}{|c|c|c|c|c|c|}
\hline & \multicolumn{4}{|c|}{ Distance from Source of Criticality } & \multirow[b]{2}{*}{$\mathrm{NSB}^{\mathrm{c}}$} \\
\hline & \multicolumn{2}{|c|}{ Facility Workers ${ }^{b}$} & \multicolumn{2}{|c|}{$\mathrm{RWMC}^{\mathrm{b}}$} & \\
\hline & $10 \mathrm{~m}$ & $13 \mathrm{~m}$ & $20 \mathrm{~m}$ & $100 \mathrm{~m}$ & $6000 \mathrm{~m}$ \\
\hline Total EDE (rem) & 865 & 506 & 207 & 5.7 & $5.8 \mathrm{E}-12$ \\
\hline
\end{tabular}

\section{a. Reny, 1992}

b. EDEs for facility workers and RWMC personnel based on initial criticality burst of $1.0 \mathrm{E}+18$ fissions. It is assumed personnel at the RWMC would be evacuated immediately.

c. EDEs for the maximum exposed individual at the nearest site boundary (NSB) based on the full one-hour duration of accident with total of $2.14 \mathrm{E}+18$ fissions.

to workers at $10 \mathrm{~m}$ are $865 \mathrm{rem}$, at $13 \mathrm{~m}(42.6 \mathrm{ft})$ are $506 \mathrm{rem}$, and at $20 \mathrm{~m}(65.6 \mathrm{ft})$ are $207 \mathrm{rem}$. Workers within $13 \mathrm{~m}$ of the criticality would receive a fatal dose. The $207 \mathrm{rem}$ dose to a worker at $20 \mathrm{~m}(65.6 \mathrm{ft})$, could result in radiation sickness and an increased risk of fatal cancer of 8 in 100 . The dose to a worker at $100 \mathrm{~m}$ ( $328 \mathrm{ft}), 5.7 \mathrm{rem}$, would exceed the annual limit for radiation workers (5 rem) specified in DOE Order 5480.11 and could result in higher than expected cancer incidence in that individual (increased risk of fatal cancer $=1$ in 500). Doses to the MEI at the nearest site boundary (5.8 E-12 rem) would not cause a significant increased risk of a fatal cancer (increased risk to MEI receptor are less than 1 in 1 trillion). Remotely controlled operating equipment, the process design, and the use of extensive monitoring equipment would lower the consequences of a criticality accident. Administrative controls would be in place to limit personnel access to the waste processing area.

No nonradiological, hazardous materials releases beyond those being released from routine operations, are postulated for this accident.

EDEs resulting from particulate air emissions from this accident are summarized in Table A-16. For the unmitigated release scenario, the total dose to a worker at $100 \mathrm{~m}(328 \mathrm{ft})$ is $28,000 \mathrm{mrem}$, which exceeds the annual limit for radiation workers $(5000 \mathrm{mrem})$ specified in DOE Order 5480.11 and could result in higher than expected cancer incidence in that individual (increased risk of fatal cancer $=1$ in 100). Doses to individuals at EBR-I and the NSB would not cause a significant increased risk of a fatal cancer (increased risk to EBR-I receptor $=7$ in 100,000).

EDEs from the mitigated release scenario would be far below levels expected to cause any adverse health effects, and on the average are hundreds of thousands of times lower than the doses in the unmitigated scenario. The total dose to the worker at $100 \mathrm{~m}(4.3 \mathrm{E}-02 \mathrm{mrem})$, for example, would result in an increased risk of a fatal cancer of 17 in 1 billion. 
Table A-16. Radiological consequences (EDE, mrem) of criticality in the waste processing area.

\begin{tabular}{|c|c|c|c|c|c|c|}
\hline \multirow[b]{2}{*}{ Pathway } & \multicolumn{3}{|c|}{ Unmitigated release } & \multicolumn{3}{|c|}{ Mitigated release } \\
\hline & $\begin{array}{c}\text { Worker at } \\
100 \mathrm{~m}\end{array}$ & EBR-I & NSB & $\begin{array}{c}\text { Worker at } \\
100 \mathrm{~m}\end{array}$ & EBR-I & NSB \\
\hline Inhalation & $2.9 E+03$ & $1.4 \mathrm{E}+01$ & $5.7 \mathrm{E}+00$ & $6.8 \mathrm{E}-03$ & 8.0E-05 & 4.2E-05 \\
\hline Air immersion & $2.3 \mathrm{E}+04$ & $1.1 \mathrm{E}+01$ & $3.2 \mathrm{E}+01$ & $2.8 \mathrm{E}-02$ & 2.1E-04 & 7.6E-05 \\
\hline Ground surface & $2.0 \mathrm{E}+03$ & $9.7 \mathrm{E}+00$ & $4.0 \mathrm{E}+00$ & $8.9 E-03$ & 9.4E-05 & $4.4 \mathrm{E}-05$ \\
\hline Ingestion & $\mathrm{NA}^{\mathbf{a}}$ & $\mathrm{NA}^{\mathrm{a}}$ & $9.0 \mathrm{E}-01$ & $N^{*}$ & $N^{2}$ & $1.7 \mathrm{E}-04$ \\
\hline Total & $2.8 \mathrm{E}+04$ & $1.3 E+02$ & $4.3 E+01$ & $4.3 \mathrm{E}-02$ & $3.9 \mathrm{E}-04$ & 3.3E-04 \\
\hline
\end{tabular}

a. Workers and visitors to EBR-I would not incur an ingestion dose. 
In both the mitigated and unmitigated scenarios it is assumed there would be no releases of nonradiological, hazardous materials from this accident, beyond those already being released from routine operations.

\section{A-5.3 Criticality During Waste Excavation}

This accident scenario postulates that sufficient plutonium is encountered during excavation and combined to form a critical mass. This scenario is considered incredible because retrieved waste would not be accumulated during excavation, but rather, moved on to be processed. Thus, there is no "reasonably conceivable scenario" (Elder, 1986) during excavation for combining the necessary mass of plutonium to form a critical mass.

Similar to the criticality in the waste processing area, $1 E+18$ fissions of plutonium-239 was postulated. The reaction continues until the moderator is boiled away, shutting down the reaction 5 minutes after it began. For the unmitigated release scenario, HEPA filters are assumed to be destroyed, releasing all of 1 year's (208 days) accumulation of radioactive and nonradioactive, hazardous particulates. Those particulates and the Fission products would be released out the retrieval enclosure stack (see Section A-4).

For the unmitigated release scenario, the release of HEPA filter accumulation accounts for the majority of doses (see Table A-17). Workers inside the facility would be subjected to acute radiation exposures and some fatalities could be expected. Doses from direct radiation would be the same as from the criticality during waste processing (Section A-5.2). The EDE to the $100 \mathrm{~m}$ worker from particulate exposure, $2.2 \mathrm{E}+05 \mathrm{mrem}$, would result in an increased risk of fatal cancer of 9 in 100 . Doses to individuals at EBR-I and the NSB, 2700 and $1400 \mathrm{mrem}$, could result in increased fatal cancer risks of 1 in 1000 and 7 in 10,000, respectively.

EDEs resulting from particulate release from the mitigated release scenario would be far below levels expected to cause any adverse health effects; the dose to the worker at $100 \mathrm{~m}(0.097 \mathrm{mrem})$, for example, would result in an increased risk of a fatal cancer of 4 in 100 million.

For both mitigated and unmitigated release scenarios, there would be no releases of nonradiological, hazardous materials from this hypothetical accident, beyond those already being released from routine operations. 
Table A-17. Radiological consequences (EDE, mrem) of a criticality during waste retrieval.

\begin{tabular}{|c|c|c|c|c|c|c|}
\hline \multirow[b]{2}{*}{ Pathway } & \multicolumn{3}{|c|}{ Unmitigated release } & \multicolumn{3}{|c|}{ Mitigated release } \\
\hline & $\begin{array}{c}\text { Worker at } \\
100 \mathrm{~m}\end{array}$ & EBR-I & NSB & $\begin{array}{c}\text { Worker at } \\
100 \mathrm{~m}\end{array}$ & EBR-I & NSB \\
\hline Inhalation & $2.2 E+05$ & $2.7 \mathrm{E}+03$ & $1.3 \mathrm{E}+03$ & $1.0 \mathrm{E}-02$ & $2.9 \mathrm{E}-04$ & $1.2 \mathrm{E}-04$ \\
\hline Air immersion & $7.5 E+02$ & $1.4 \mathrm{E}+00$ & $6.1 \mathrm{E}+01$ & $7.5 \mathrm{E}-02$ & 4.1E-04 & $9.2 \mathrm{E}-05$ \\
\hline Ground surface & $1.2 \mathrm{E}+02$ & $3.5 \mathrm{E}-01$ & $1.4 \mathrm{E}-01$ & $1.2 \mathrm{E}-02$ & $3.5 \mathrm{E}-04$ & $1.4 \mathrm{E}-04$ \\
\hline Ingestion & $\mathbf{N A}^{\mathbf{a}}$ & $N^{2}$ & $5.1 \mathrm{E}-01$ & $\mathrm{NA}^{*}$ & $N A^{2}$ & $5.0 \mathrm{E}-04$ \\
\hline Total & $2.2 \mathrm{E}+05$ & $2.7 E+03$ & $1.4 \mathrm{E}+03$ & 9.7E-02 & $1.1 \mathrm{E}-03$ & 8.5E-04 \\
\hline
\end{tabular}


HIs (Table A-18) for nonradioactive, hazardous particulates released from HEPA filters in the unmitigated release scenario would exceed one for all receptors. This implies that this accident would pose an unaccestable noncarcinogenic health risk to the exposed individuals. In the mitigated release scenario, there would be no releases of nonradioactive, hazardous materials above those expected from routine operations.

\section{A-6. CUMULATIVE IMPACTS}

Various facilities and activities have been planned or undertaken at the RWMC relating to retrieval, examination, repackaging, and storage of wastes. The facilities located at the RWMC include the Subsurface Disposal Area, the Transuranic Storage Area, and administrative facilities (see Figure 1). Existing buildings in the Transuranic Storage Area include the Certification and Segregation/Air Support Building 2 and the Drum Venting Facility. Planned facilities include the Transuranic Storage Area Retrieval Enclosure, Waste Storage Facility, and Waste Characterization Facility.

Most of the exposure/dose information for routine facility operations at the RWMC was drawn from existing environmental documents (DOE, 1992a; Irving et al., 1991). External radiation exposures resulting from gamma radiation from waste containers were calculated for workers in the Stored Waste Examination Pilot Plant office building [approximately 440 meters $(1,444$ feet) southeast from Pit 9]. Detailed methodology is presented in DOE (1992a). The Stored Waste Examination Pilot Plant office building is used because, of all the office buildings at RWMC, it receives the highest cumulative gamma radiation dose from RWMC activities. The bounding annual occupational dose of $\mathbf{4 4}$ millirem to an office worker at the Stored Waste Examination Pilot Plant from gamma radiation is well below the DOE 5.0 rem limit for radiation workers and below the as low as reasonably achievable goal of $1.5 \mathrm{rem}$ at the RWMC. This dose is the total of the incremental gamma dose expected from Pit 9 operations and from the Certified \& Segregated Waste Storage/Air Support Building.

The estimated EDE the MEI at the INEL boundary from Pit 9 activities is 0.13 millirem (see Section A-4). The largest potential dose from all other RWMC activities is $0.0004 \mathrm{mrem}$. Therefore, the cumulative MEI EDE at RWMC from Pit 9 is 0.1304 mrem. The additional EDE of 0.1304 mrem to the MEI from all waste retrieval and processing activities at RWMC (including Pit 9) would be below the $10-\mathrm{mrem} /$ year standard of EPA ( 40 CFR 61 ) for members of the public. No atverse health effects would be expected to result from the cumulative effects of RWMC operations combined with the proposed Pit 9 excavation and remediation activity.

Radiological and nonradiological impacts of atmospheric releases were added for all facilities for a worker exposed at 100 meters (328 feet) from the facilities and a MEI at the boundary of INEL [approximately 5.9 kilometers ( 3.7 miles) south-southwest from facilities at the RWMC]. The exposures to a worker at 100 meters ( 328 feet) are not actually additive because the 100 -meter locations are different for each facility (see Section A-8).

The Pit 9 project was also evaluated in terms of its cumulative impact on dose to the maximum exposed individual from all INEL activities. The estimated EDE to a maximum exposed member of the public resulting from all radioactive atmospheric releases from INEL in 1991 was $0.004 \mathrm{mrem}$ (DOE, 1992b). The additive dose from the Waste Experimental Reduction Facility, the Tank Farm replacement project at the Idaho Chemical Processing Plant, the Test Reactor Area Warm Waste 
Pond, and proposed RWMC activities (including Pit 9 excavation and remediation) was estimated to be $0.3 \mathrm{mrem} / \mathrm{y}$ or less. This is also within the 10-mrem/y standard of EPA ( 40 CFR 61). Doses from other facilities on INEL are not actually additive because the MEI locations are different for each facility.

Table A-18. HIs resulting from hazardous particulate releases (unmitigated scenario) from a criticality during waste retrieval."

\begin{tabular}{llll} 
& \multicolumn{3}{c}{ Hazard quotient } \\
\cline { 2 - 4 } Particulate & $100 \mathrm{~m}$ & EBR-I & NSB \\
\hline Mercury & $4 \mathrm{E}-01$ & $5 \mathrm{E}-01$ & $3 \mathrm{E}-01$ \\
Lead & $9 \mathrm{E}+00$ & $1 \mathrm{E}-01$ & $7 \mathrm{E}+00$ \\
Asbestos & $9 \mathrm{E}+00$ & $1 \mathrm{E}+01$ & $6 \mathrm{E}+00$ \\
Lithium & $8 \mathrm{E}-02$ & $9 \mathrm{E}-02$ & $6 \mathrm{E}-02$ \\
Beryllium & $2 \mathrm{E}+01$ & $3 \mathrm{E}+01$ & $2 \mathrm{E}+01$ \\
Hazard index & $4 \mathrm{E}+01$ & $5 \mathrm{E}+01$ & $3 \mathrm{E}+01$
\end{tabular}

a. There would be no releases above those from normal operations of nonradiological particulates in the mitigated release scenario. 
Table A-19. Estimated cumulative radiological doses from existing and proposed major INEL activities.

\begin{tabular}{|c|c|c|}
\hline Activity/Facility & MEI (mrem/yr) & $\begin{array}{c}\text { Population } \\
\text { (person-rem/yr) }\end{array}$ \\
\hline Present INEL & 4.1E-03 & $-b^{b}$ \\
\hline Test Reactor Area Evaporation Basin ${ }^{c}$ & $1.6 \mathrm{E}-04$ & $--^{b}$ \\
\hline ICPP HLW ${ }^{d}$ Tank Farm Replacement ${ }^{c}$ & $1.1 \mathrm{E}-03$ & $5.2 \mathrm{E}-03$ \\
\hline WERF $^{c}$ & $<1.6 \mathrm{E}-01$ & $<5.7 \mathrm{E}-01$ \\
\hline Pit 9 Cleanup & $1.3 \mathrm{E}-01$ & 2.7E-01 \\
\hline Other RWMC Activities ${ }^{c, s}$ & 4.0E-04 & $6.0 \mathrm{E}-04$ \\
\hline Total & $<3.0 \mathrm{E}-01$ & 8.5E-01 \\
\hline \multicolumn{3}{|c|}{$\begin{array}{l}\text { a. Calculated value based on measured emissions (DOE, 1992a), } \\
\text { b. Not calculated in DOE, 1992a. } \\
\text { c. Calculated values based on maximum release scenarios; estimates may change if } \\
\text { additional project proposals are developed or plans for listed projects are modified. } \\
\text { d. ICPP HLW-Idaho Chemical Processing Plant High-Level Waste. } \\
\text { e. Includes Drum Venting Facility, Waste Characterization Facility, Retrieval and } \\
\text { Re-Storage, and Waste Storage Facilities. }\end{array}$} \\
\hline
\end{tabular}


Table A-20. Cumulative nonradiological impacts from activities related to transuranic retrieval from the Transuranic Storage Area at the RWMC.

\begin{tabular}{|c|c|c|c|c|}
\hline \multirow[b]{2}{*}{ Facility } & \multicolumn{2}{|c|}{$\begin{array}{l}\text { Non-carcinogenic risk } \\
\text { (HI) }\end{array}$} & \multicolumn{2}{|c|}{ Carcinogenic risk } \\
\hline & $100 \mathrm{~m}$ worker & MEI & $100 \mathrm{~m}$ worker & MEI \\
\hline Pit 9 & IE-04 & $3 E-02$ & $3 E-09$ & $2 \mathrm{E}-09$ \\
\hline DVF and C\&S/ASB-2 & $2 \mathrm{E}-07$ & SE-07 & $1 E-07$ & $5 E-09$ \\
\hline ICPP & $N A^{*}$ & $N A^{*}$ & $\mathrm{NA}^{*}$ & $\mathrm{NA}^{\star}$ \\
\hline WERF & $\mathrm{NA}^{b}$ & $N^{\circ}$ & $N^{d}$ & $6 E-05$ \\
\hline Total & $1 E-04$ & $3 E-02$ & IE-07 & $6 \mathrm{E}-05$ \\
\hline
\end{tabular}

a. $\mathrm{NO}_{\mathrm{x}}$ and $\mathrm{SO}_{2}$ are the major non radioactive emissions anticipated from all ICPP sources. The estimated average annual concentrations due to the simultaneous operation of all $\mathrm{NO}_{\mathrm{x}}$ and $\mathrm{SO}_{2}$ emission sources on the INEL at the INEL boundary are well below EPA ambient air quality standards (DOE, 1987).

b. Concentration of noncarcinogenic chemicals for WERF operations are at least 200 times below the applicable TLV (Staley, 1992a).

c. Concentration of noncarcinogenic chemicals for WERF operations are at least 16,000 times below the applicable TLV (Staley, 1992a).

d. Concentrations of all chemicals are below applicable TLVs (Staley, 1992a). 


\section{A-7. REFERENCES}

American Conference of Governmental Industrial Hygienists (ACGIH) 1989, Threshold Limit Values and Blological Exposure Indices for 1989-1990. Cincinnati, Ohio.

Brodie, R. W., 1988, Screening Procedures for Estimating the Air Quality Impact of Stationary Sources, EPA-450/4-88-010.

DOE Order 6430.1A. 1989, "General Design Criteria."

DOE Order 5400.5, 1990, "Radiation Protection of the Public and the Environment".

DOE, 1991, The Idaho National Engineering Laboratory Site Environmental Report for Calendar Year 1990, DOE/ID-12082(90).

DOE, 1992, Environmental Assessment for the Retrieval and Restorage of Transuranic Storage Area Waste at the Idaho National. Tngineering Laboratory, DOE/EA 0692.

DOE, 1987, Environmental Assessment: Fuel Processing Restoration at the Idaho National Engineering Laboratory, DOE/EA 0306

DOE Order 5480.23, 1992, "Nuclear Safety Analysis Reports."

Elder, J. C. et a., 1986, A Guide to Radiological Accident Considerations for Siting and Design of DOE Nonreactor Nuclear Facilities, Los Alamos National Laboratory, LA-10294-MS.

EPA, 1986, Superfund Public Health Evaluation Manual, EPA-540-1-86-060.

EPA, 1989a, Risk Assessment Guidance for Superfund, Volume 1, Human Health Evaluation Manual (Part A), EPA-540-1-89-002.

EPA, 1989h, Health Effects Assessment Summary Tables, Fourth Quarter FY 1989. OERR 9200.6-303-(89.4).

EPA, 1989c, The Clean Air Act Assessment Package-1988 (CAP-88), Office of Radiation Programs.

Idaho Air Quality Bureau, 1989, State of Idaho Guidance Manual for Obtaining a Permit to Construct, Modify or Operate un Air Pollution Source, Draft, October 1989.

Irving, J. S., M. G. Gratson, P. R. Leonard, S. J. Maheras, and C. S. Staley, 1991. Supplement Analysis of Transuranic Waste Characterization and Repackaging Activities at the Idaho National Engineering Laboratory in Support of the Waste Isolation Pilot Plant Test Program. EGG-EST-9346, May.

NRC (U.S. Nuclear Regulatory Commission), 1979. Assumptions Used for Evaluating the Potential Radlological Consequences of Accidental Nuclear Criticality in a Plutonium Processing and Fuel Fabrication Plant, Regulatory Guide 3.35, Revision 1, July. 
NIOSH, 1990 Pocket Guide to Chemical Hazards, National Institute for Occupational Safety and Health.

Reny, D. A., 1992, Draft Preliminary Hazard Classification for the Plt 9 Comprehensive Demonstration, EGG-WM-9966, December.

Staley, C. S., 1992a, Hazardous Chemical Releases Resulting from Pit 9 Waste Retrieval at the RWMC, EG\&G Idaho Inc. Amended Engineering Design File No. RWMC-91-004.2, Revision 1.

Staley, C. S., 1992b. Radiological Impacts from Routine Operations of Pit 9 Waste Retrieval, EG\&G Idaho Inc. Amended Engineering Design File No. RWMC-91-004, Revision 1.

Staley, C. S., 1992c, Runs Supporting Source Term Development for WERF Restart, EG\&G Iduho Inc. Amended Engineering Design File No, WERF-91-001.2, Revision 1.

Staley, C. S., 1992d, Derived Source Limits for Non Radiologic Waste Constituents for the WERF Incinerator, EG\&G Idaho Inc. Engineering Design File No. WERF-91-001.1.

Walton, J. C., A. S. Rood, R. G. Baca, and M. D. Otis, 1989, "Model for Estimation of Chlorinated Solvent Release from Waste Disposal Sites," Journal of Huzardous Material, 21, pp. 15-34.

Wenzel, D. R., 1990, Interim Users Manual for RSAC-4 Radiological Safery Analysis Computer Program, Version 4.03, Westinghouse Idaho Nuclear Company, Inc.

Wierman, T. E., 1991, Pit 9 Comprehensive Demonstration Hazard Class Plutonium Source Term, EG\&G Idaho, Inc., Engineering Design File No. ERP.BWP-66. 

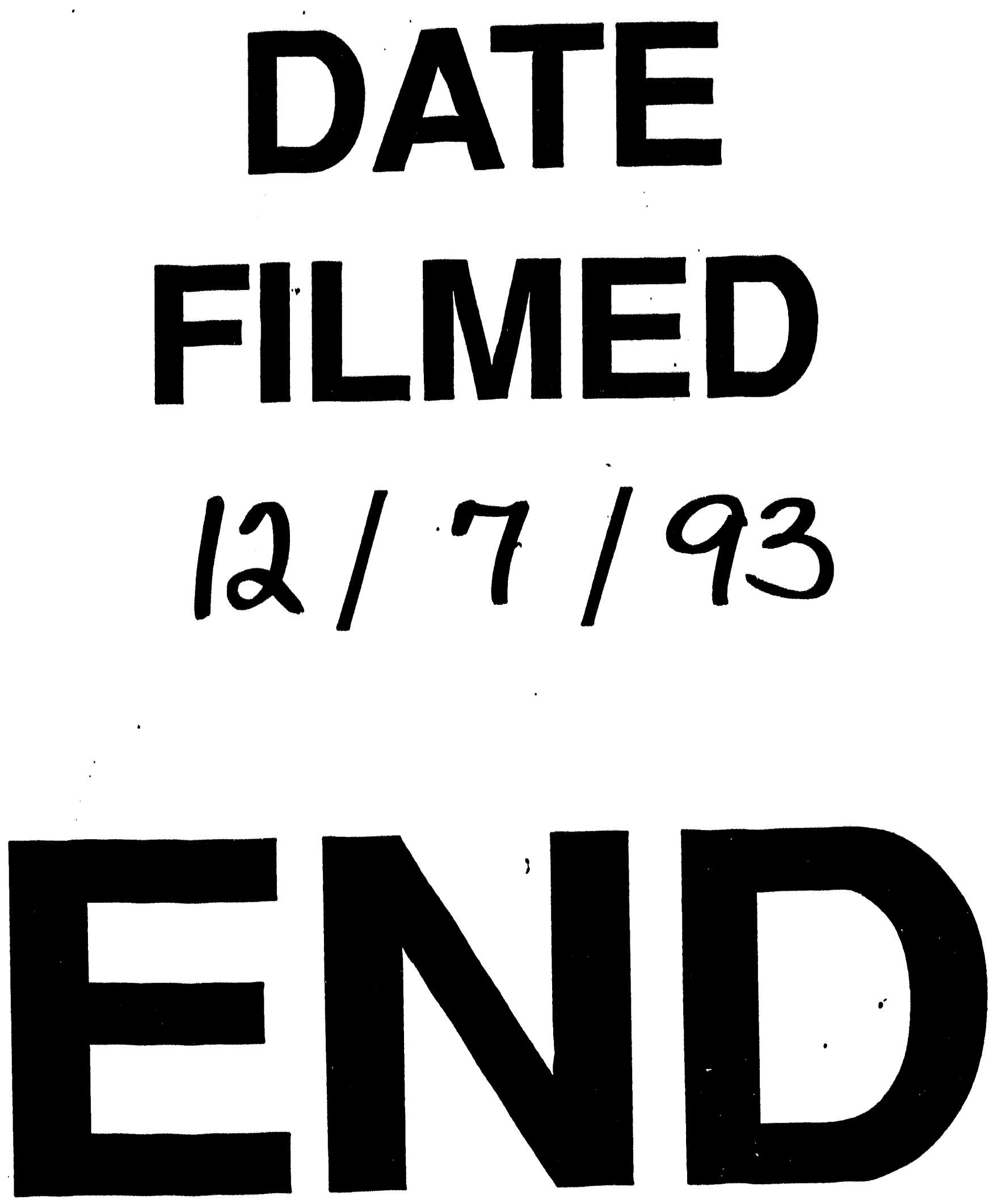

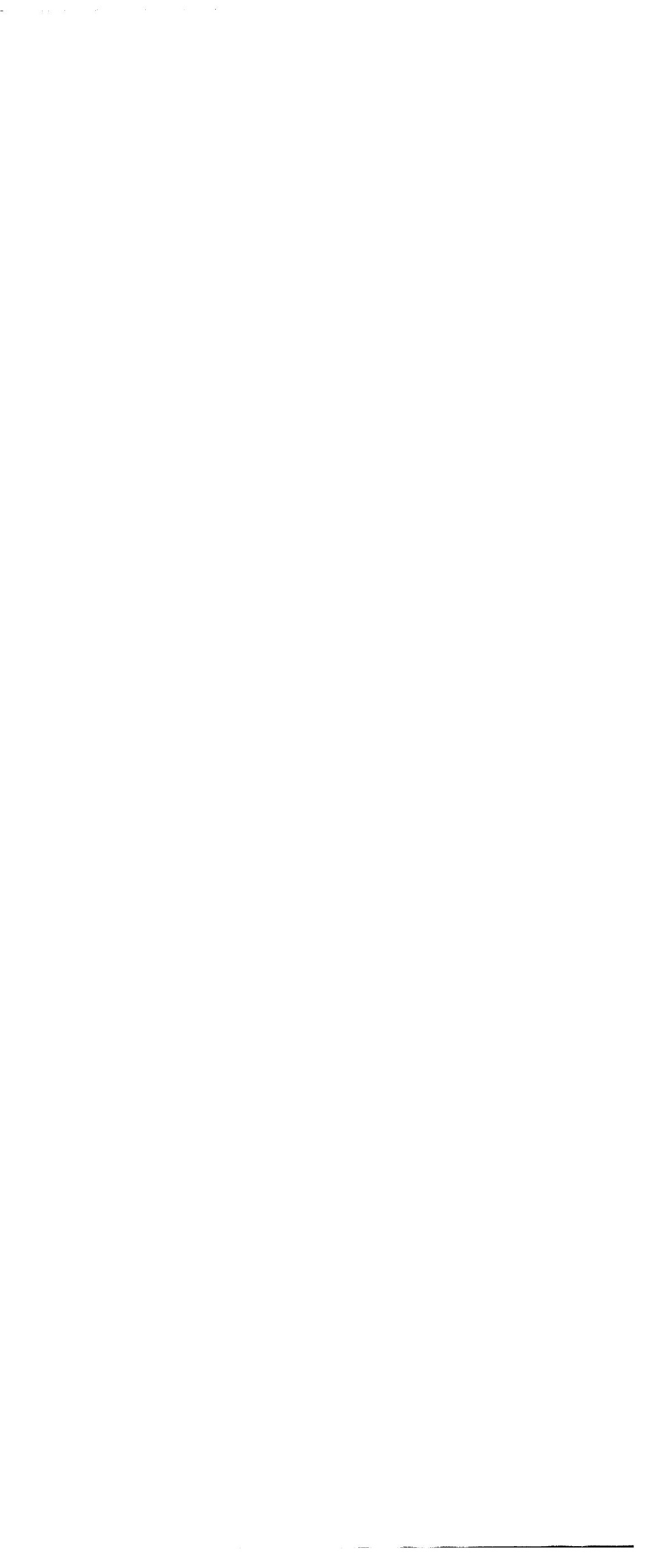